\title{
General Principals of miRNA Biogenesis and Regulation in the Brain
}

\author{
Dónal O’Carroll ${ }^{1}$ and Anne Schaefer ${ }^{\star 2}$ \\ ${ }^{1}$ European Molecular Biology Laboratory, Mouse Biology Unit, Monterotondo Scalo, Italy; ${ }^{2}$ Fishberg Department of \\ Neuroscience and Friedman Brain Institute, Mount Sinai School of Medicine, New York, NY, USA
}

\begin{abstract}
MicroRNAs (miRNAs) are small, noncoding RNAs that mediate posttranscriptional gene suppression in a sequence-specific manner. The ability of a single miRNA species to target multiple messenger RNAs (mRNAs) makes miRNAs exceptionally important regulators of various cellular functions. The regulatory capacity of miRNAs is increased further by the miRNA ability to suppress gene expression using multiple mechanisms that range from translational inhibition to mRNA degradation. The high miRNA diversity multiplied by the large number of individual miRNA targets generates a vast regulatory RNA network than enables flexible control of mRNA expression. The gene-regulatory capacity and diversity of miRNAs is particularly valuable in the brain, where functional specialization of neurons and persistent flow of information requires constant neuronal adaptation to environmental cues. In this review we will summarize the current knowledge about miRNA biogenesis and miRNA expression regulation with a focus on the role of miRNAs in the mammalian nervous system.
\end{abstract}

Neuropsychopharmacology Reviews (2013) 38, 39-54; doi: I0.1038/npp.20 I2.87; published online 6 June 2012

Keywords: miRNA biogenesis; miRNA expression; brain; neurons

\section{INTRODUCTION}

The ability of microRNAs (miRNAs) to target the majority of genes in humans and mice presents miRNAs as important regulators of diverse cellular phenotypes that occur within the range of cell differentiation limits. The degree of phenotypic fluctuation varies between cells of different types and depends largely on the complexity of the cell tasks, cell engagements in multiple intercellular interactions, as well as the cell's exposure to a diversity of environmental signals. Nowhere in the body is the complexity of a single cell's morphology and function as rich as in the brain. In addition to their perinuclear cell soma, each neuron grows a single axon that can extend up to $1 \mathrm{~m}$ in length in humans and various numbers of dendrites that create a complex three-dimensional 'dendritic tree.' Dendrites branch and spread up to hundreds of $\mu \mathrm{m}$ around the neuronal soma and contribute to the formation of numerous neuronal circuits with different functional outputs. Depending on the neuron type, dendrites can carry

\footnotetext{
${ }^{*}$ Correspondence: Dr A Schaefer, Department of Neuroscience, Mount Sinai School of Medicine, One Gustave L. Levy Place, Box 1065, New York, NY 10029, USA, Tel: +1 917420 0395, Fax: + 1212327 7746, E-mail: anne.schaefer@mssm.edu

Received 6 March 2012; revised 2 May 2012; accepted 2 May 2012
}

up to 17.5 synapses/ $\mu$ m (Napper and Harvey, 1988a, b) that wire excitatory or inhibitory signals through the neuronal networks. With the estimate of 100-200 billion neurons in the human brain, each individual neuron being synaptically connected to $\sim 5000-200000$ neurons, the complexity of information processed exceeds by far any other system in the human body. The morphological and functional specialization of individual neurons and their corresponding networks are at the core of the systems complexity and depend on a highly organized gene expression program. In nonneuronal cells, mRNA translation occurs almost exclusively at the rough endoplasmic reticulum in a close proximity to the nucleus. Although a similar translational compartment exists in neurons, autonomously managed protein translation has been demonstrated to occur in dendrites and axons, and in particular at active synapses and growth cones (Jung et al, 2012; Steward and Schuman, 2003). The relative autonomy of local mRNA translation regulation implies the existence of a mechanism that enables local control of gene expression upon synaptic activation/inhibition as well as the coupling of this process with the regulation of gene expression in the neuronal nuclei. The recent discovery of the presence of miRNAs and the protein complexes involved in miRNA biogenesis and function in neuronal soma, dendrites, and axons suggested 
their potential involvement in the regulation of protein translation in all three compartments. Moreover, the presence of the same miRNA in the neuronal soma as well as in distant dendrites might indicate their potential to help coordinating the spatially restricted translational processes. The complex nature of miRNA-dependent gene expression regulation could present an effective mechanism to ensure the tight control of neuronal gene expression required for the regulation of neuronal development, function, and survival.

In the current review we will summarize the general principals of miRNA biogenesis and function. We will discuss the various mechanisms that contribute to the regulation of miRNA expression, stability, and activity with a specific focus on the role of miRNAs in the nervous system.

\section{GENERAL MECHANISMS OF miRNA FUNCTION}

The first evidence for the existence of miRNAs as well as their important regulatory role has been obtained by the discovery of the small endogenous RNA lin-4 as essential regulator of cell-fate determination in the $C$. elegans larvae. This effect of lin- 4 was caused by its ability to downregulate the expression of the transcription factor lin-14, whose temporal decrease is critical during the L1-L3 larval cell stage progression (Ambros and Horvitz, 1984; Lee et al, 1993). An additional proof for the ability of miRNAs to regulate gene expression has been obtained by the discovery of second miRNA let-7 that controls L3-L4 larvae cell stage progression during C. elegans development by targeting lin-41 (Pasquinelli et al, 2000; Reinhart et al, 2000). Since the discovery of let-7, more than 1000 distinct miRNAs have been described and annotated in various organisms ranging from algae to humans (www.mirbase.org; Griffiths-Jones, 2006).

\section{miRNA Biogenesis}

miRNA genes are encoded within the genome, suggesting that their transcription might be tightly coordinated with the transcription of other genes including the proteincoding genes that serve either as a source of miRNAs or as their targets. The genomic origin of miRNAs raises the question about the mechanism that either supports or discriminates against simultaneous expression of proteincoding genes and miRNAs. The most common mechanism of transcriptional segregation between specific proteincoding genes and miRNA gene relies on the localization of $\sim 50 \%$ of mammalian miRNA-coding genes within the intergenic space. Most of the intergenic miRNAs are autonomously expressed and possess their own enhancer and promoter elements (Corcoran et al, 2009; Lagos-Quintana et al, 2001; Lau et al, 2001; Lee and Ambros, 2001; Lee et al, 1993). Similar to protein coding genes, most miRNA genes are transcribed by RNA Polymerase II (RNA PolII) (Cai et al, 2004; Lee et al,
2004). It is therefore likely that temporal- and lineagespecific differences in miRNA and protein-coding gene expression are controlled by the expression of specific transcription factors and posttranslational chromatin modifications. This possibility is particularly plausible because of the cluster organization of several miRNA genes. miRNA genes that are clustered within $0.1-50 \mathrm{~kb}$ from each other display common expression patterns (Baskerville and Bartel, 2005). Common expression patterns of clustered miRNAs such as miRNAs from the miR-17-92 and miR-2327a-24 cluster reflect their generation from a single PolII-dependent polycistronic transcript (Lee et al, 2004). The coordinated miRNA gene expression may have a functional significance as suggested by the ability of individual miRNAs derived from the miR-17-92 cluster to contribute jointly to regulation of cell survival by targeting the pro-apoptotic protein Bim (Ventura et al, 2008). Opposite to proximally located miRNA genes, miRNA genes that are spaced more than $50 \mathrm{~kb}$ apart tend to express in a noncoordinated fashion (Baskerville and Bartel, 2005).

Approximately $40 \%$ of miRNA genes are localized within gene introns (Rodriguez et al, 2004; Smalheiser et al, 2008). Initiation of RNA PolII- or, in some cases, RNA PolIIIdependent transcription (Monteys et al, 2010; Ozsolak et al, 2008) within an intron may prevent transcription and splicing of the protein coding genes. However, experimental and bioinformatics evidence show the ability of numerous intronic miRNAs to coexpress with their host genes (Baskerville and Bartel, 2005; Lagos-Quintana et al, 2001; Lau et al, 2001; Liang et al, 2007; Rodriguez et al, 2004; Wang et al, 2009). It should be noted that the simultaneous presence of the miRNA and its host mRNA in a given tissue does not automatically imply cotranscription of the miRNA and its host gene(s). It could well be that transcription of the host genes and embedded in them miRNAs does not occur simultaneously but rater in a 'seesaw'-like fashion, thus preventing potential impact of intronic transcription on host gene splicing. Addressing this question would require GROseq (DECODE) analysis of mRNA and miRNA gene transcription (Core et al, 2008).

Approximately $10 \%$ of known miRNA genes are situated within exons and, if encoded in sense direction with the coding gene, follow the transcription patterns of their host gene(s). It is plausible that miRNAs localized within the introns or exons of cell lineage- or function-specific genes might contribute to the control of genetic networks according to the expected function of the host gene product. In support of this model, the intronic miR-208a, which is coexpressed with its heart-specific host gene Myh6, controls the suppression of negative regulators of muscle growth and hypertrophy in mice (Callis et al, 2009). Similarly, transcriptional activation of apoptosis-associated tyrosine kinase (AATK), which is essential for neuronal differentiation, leads to expression of its intronic miRNA miR-338 that suppresses mRNAs whose protein products are negative regulators of neuronal differentiation (Barik, 2008). The possible role of miRNAs as capacitators of their host gene 
function is supported by comparative analysis of host gene expression and the miRNA as well as the miRNA-target genes in different cell types (Lutter et al, 2010; Radfar et al, 2011). Intronic miRNAs can also function as direct negative regulators of their host gene expression, as shown for miR-128, which can regulate the expression levels of its host gene Arpp21 in the brain (Lin et al, 2011; Megraw and Hatzigeorgiou, 2010). The distinct evolutionary conservation of protein coding host genes and miRNAs suggest that localization of miRNAs within genes emerged in response to the environmental pressure that required a coordination of specific cell functions. In this respect it would be interesting to determine the evolutionary traits of miRNAs in conjunction with the evolution of their hosts as well as the appearance of novel regulatory networks in muticelluar organisms.

Regardless of the genomic location, generation of mature miRNAs occurs in a highly conserved fashion that involves the processing of the primary miRNA transcript in the nucleus to the mature product in the cell cytosol. The primary miRNA transcripts (pri-miRNAs) present themselves to the processing machinery not merely as specific sequences but rather as particularly shaped structures. This mode of RNA recognition reflects the ability of the pri-miRNA sequence to fold into an imperfectly paired, double-stranded stem loop structure. The pri-miRNA transcripts can form a highly complex structure containing several multiple stem loops in a row. The imperfect pri-miRNA stem loop structures are recognized by the nuclear microprocessor complex that contains two core proteins, Drosha and DGCR8 (DiGeorge syndrome critical region 8 ). DGCR8 recognizes and binds to the stem region of the pri-miRNA hairpin followed by the recruitment of Drosha and ensuing cleavage of pri-miRNA and generation of the precursor-miRNA (pre-miR) (Denli et al, 2004; Gregory et al, 2004; Han et al, 2004; Landthaler et al, 2004; Lee et al, 2003; Wang et al, 2007). The efficiency of primiRNA processing depends on the structural characteristics of individual pri-miRNA sequences. In case of miRNAs that derive from large polycistronic clusters, such as miR-17-92, the miRNAs inside the core of the highly compact tertiary structure are processed less efficiently than miRNAs on the surface of the structure (Chaulk et al, 2011). The processing of pri-miRNAs occurs co-transcriptionally and produces rapidly a pool of $\sim 60-70$-nt-long stem-loop pre-miRNAs (Morlando et al, 2008). The nascent pre-miRNAs are exported to the cytoplasm by the karyopherin protein family member Exportin-5 in a GTP-dependent fashion (Bohnsack et al, 2004; Lund et al, 2004; Yi et al, 2003). Once in the cytoplasm, the pre-miRNA is incorporated into the RISC Loading Complex (RLC) where it is processed by the type III ribonuclease Dicer_into a 21-nt-long miRNA/ miRNA* duplex (Bernstein et al, 2001; Grishok et al, 2001; Hutvagner et al, 2001; Ketting et al, 2001; Knight and Bass, 2001). The miRNA/miRNA* duplex is further processed/ unwound by members of the Argonaute family, giving raise to the mature, single-stranded $\sim 21$-nt-long miRNA
(Kwak and Tomari, 2012). The miRNA-generating process described above is currently viewed as the canonical pathway and contributes to the generation of most mammalian miRNAs (Figure 1).

\section{Noncanonical miRNA Biogenesis}

Separate pathways of miRNA generation deviate from the canonical sequential Drosha/DGCR8 and Dicer processing of pri- and pre-miR. The defining feature of a miRNA is its incorporation into the RNA-Induced Silencing Complex (RISC). According to this principal, several noncanonical pathways have been identified. The first pathway, the mirtron pathway, was initially identified in Drosophila, where the splicing and debranching of very short hairpin introns of mRNA coding genes generate pre-miRNAs independent of Drosha/DGCR8 processing that are directly exported and processed by Dicer (Figure 1; Okamura et al, 2007; Ruby et al, 2007). The mirtron pathway was subsequently shown to be conserved in vertebrates (Babiarz et al, 2011; Berezikov et al, 2007; Glazov et al, 2008) and to be truly independent of Drosha/DGCR8 activity (Babiarz et al, 2008; Chong et al, 2008; Yi et al, 2009). Opposite to Drosophila, only few mirtrons have been described in mammals so far and include miR-877, miR-702, and miR-1124-miR-1141 (Berezikov et al, 2007). RNA deepsequencing analysis comparison from Dicer-deficient and DGCR8-deficient mouse brain samples revealed the presence of a total of six brain expressed mirtrons that include the previously described, ES cell-expressed miR-877, miR-1981, and miR-702, as well as three novel mirtrons derived from introns within the Cpne7, Gnb2, and Syvn1 genes (Babiarz et al, 2011). In addition to mirtrons, a few tRNA and snoRNA derived-fragments have been shown to enter the RISC complex independently of Drosha/DGCR8 but in a Dicer-dependent manner (Babiarz et al, 2008; Bak et al, 2008; Ender et al, 2008). DGCR8 deletion specifically eliminates the canonical miRNA biogenesis pathway and has been used to reveal the contribution of the canonical miRNA pathway in ES cells, skin development, cardiovascular development, mature cardiomyocyte function and survival, as well as excitatory neuron function and survival (Babiarz et al, 2011; Kanellopoulou et al, 2005; Rao et al, 2009; Wang et al, 2007; Yi et al, 2009).

A novel Drosha-dependent but Dicer-independent noncanonical pathway for the generation of miRNA was uncovered recently. This pathway relies on Ago2 and specifically on its unique endonuclease activity required for the pre-miRNA cleavage event (Cheloufi et al, 2010; Cifuentes et al, 2010; Yang et al, 2010). To date, only a sole miRNA, miR-451, has been shown to employ this mechanism, although the full contribution of the Ago2dependent pathway remains to be explored. The miR-451 is required for normal erythropoietic development/homeostasis (Patrick et al, 2010; Rasmussen et al, 2010; Yu et al, 2010), and in the hematopoietic system is solely expressed within the erythroid lineage (Rasmussen and O'Carroll, 


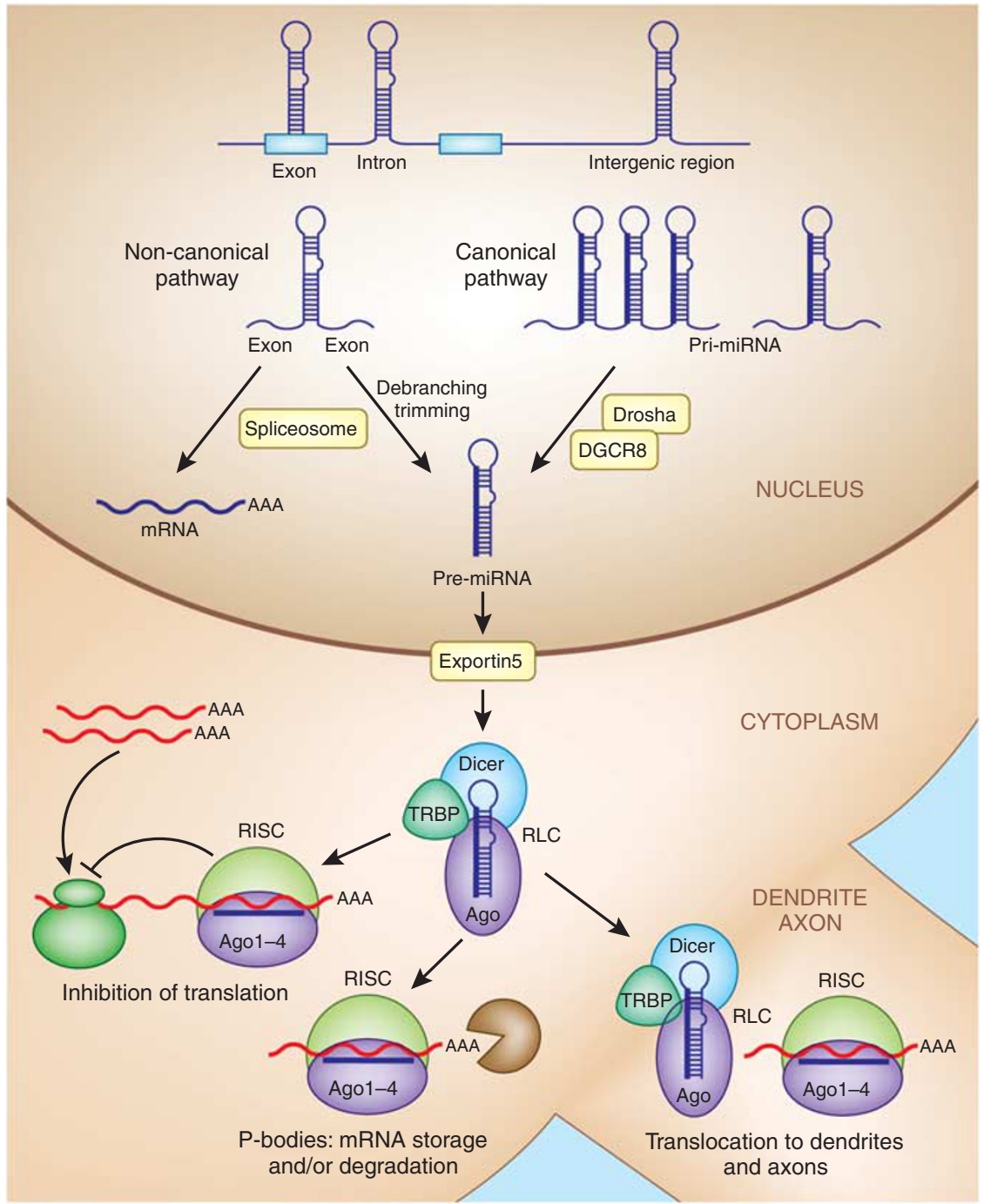

Figure 1. Schematic overview of canonical and noncanonical miRNA biosynthesis. The canonical miRNA pathway produces pri-miRNA transcripts from miRNA genes encoded in exonic, intronic, or intergenic regions, followed by Drosha/DGCR8 processing of the pri-miRNA transcripts into premiRNAs. Intronic pre-miRNA hairpins of the noncanonical mirtron pathway are formed by splicing, debranching, and trimming of short introns without Drosha processing. Pre-miRNAs generated by the canonical and noncanonical pathways are exported from the nucleus via Exportin 5, followed by subsequent Dicer cleavage within the RISC loading complex (RLC), unwinding of the miRNA/miRNA* duplex via Argonaute, and TRBP-dependent loading into the RNA-induced silencing complex (RISC). Binding of target mRNAs to miRNAs in RISC is followed by inhibition of translation and/or mRNA degradation within p-bodies in the cytosol. The transport of RLC and RISC into the dendritic and axonal compartments occurs via a still unknown mechanism.

2011)). However, in addition to its essential role in erythropoiesis, this unique miRNA has recently been shown to be important in a defined neuropathology. The miR-451 regulates glioma migration and proliferation in response to metabolic stress (Godlewski et al, 2010).

\section{RNA-Induced Silencing Complex}

Once generated, miRNAs become an integral part of the effector RISC. The miRNA-carrying RISC includes Dicer, the RNA-binding Argonaute proteins (Tan et al, 2011), and the adaptor protein TRBP, a double-stranded RNA-binding protein (Chendrimada et al, 2005) that connects Dicer and Ago proteins and loads small interfering RNA into the RISC.
Generally, one strand of the intermediate miRNA duplex, the nascent miRNA, is loaded into RISC (Khvorova et al, 2003; Schwarz et al, 2003). However, some miRNAencoding loci can incorporate both strands into RISC. The binding of miRNAs to RISC is mediated by the PAZ and MID domains of Ago proteins (Lingel et al, 2003; Song et al, 2003; Yan et al, 2003).

The mouse and humans genomes encode four Ago proteins (Ago 1-4). The distinct Ago proteins appear to bind a similar pool of miRNAs and mRNA targets (Burroughs et al, 2011; Czech and Hannon, 2011; Landthaler et al, 2008). However, only Ago 2 can catalyze the cleavage (slicing) of target mRNAs that are perfectly complementary to the miRNA (Liu et al, 2004; Meister et al, 2004; Song et al, 
2003). The slicer function of Ago2 does not play a major role in miRNA gene suppression in mammals. The high abundance of Ago2 in various tissues suggests a possible dominant role of Ago2 in miRNA-mediated gene suppression and hence cell function. Indeed, deficiency in Ago2 results in death of mice during early embryogenesis or during mid gestation (Alisch et al, 2007; Liu et al, 2004; Morita et al, 2007). However, the essential role of Ago2 in embryonic development may reflect not only impaired miRNA-mediated gene suppression, but also defective miRNA generation. In fibroblasts, deficiency in Ago2 results in downregulation of the expression levels of a defined group of miRNAs. The stability of these nascent miRNAs is strictly dependent upon binding to an Ago2 protein (Diederichs and Haber, 2007; O'Carroll et al, 2007). The specific role of Ago1, 3, and 4 in miRNA function remains elusive. The individual deficiencies in Ago1, 3, and 4 genes have no obvious impact on mouse well-being, thus suggesting a potential redundancy between Ago 1, 3, and 4 as well as between Ago2 and the rest of the Ago family (O’Carroll et al, 2007).

\section{miRNA Targeting and Mechanisms of Silencing}

The miRNAs bound within the Ago protein target the RISC complex through sequence complementarity to its target mRNAs. The degree of complementarity defines the mechanism and degree of silencing. As previously stated, full complementarity between miRNA and its mRNA targets will direct Ago2-mediated endonucleolytic cleavage and destruction of the mRNAs (Hammond et al, 2001; Hutvagner and Zamore, 2002). This mechanism is very rarely employed in the animals, with one example to date postulated in mammals (Hornstein et al, 2005; Yekta et al, 2004). Animal miRNAs generally display partially complementarity with mismatches of the miRNA/mRNA duplexes in the central region. These mismatches or bulges prevent Ago2-dependent cleavage of the mRNA (Hutvagner and Zamore, 2002). The initial bases of the miRNA sequence play the important role in defining the mRNA targets. Bases 2-7, known as the miRNA 'seed', are responsible for the definition of target specificity (Doench and Sharp, 2004). These bases generally must pair with perfect complementarity with the target mRNA, and often pairing $3^{\prime}$ prime of the seed is observed in bone fide targets. The importance of the seed sequence was underscored through the analysis of an ENU-induced mutation diminuendo in mice that presented progressive hearing loss. The diminuendo mutation was found to be a point mutation in the seed sequence of miR-96 and homozygotes not only show a loss of normal miR-96 target regulation, but the de novo targeting of transcripts with the 'new' mutant miR-96 seed (Lewis et al, 2009). Most of the miRNA-binding sites are located within the $3^{\prime}$ UTR of the targeted mRNA. Usually, the binding of multiple miRNAs per $3^{\prime}$ UTR, either of the same or different miRNAs, will increase the level and effectiveness of mRNA repression. Although the initial hypothesis was that functional miRNA/RISC-binding sites were restricted to the $3^{\prime}$ UTR, recent data involving both artificial and natural miRNAs as well as Ago2-bound target mRNA sequencing have shown functional sites to reside in the $5^{\prime} \mathrm{UTR}$ or coding mRNA region (Chi et al, 2009; Easow et al, 2007; Gu et al, 2009; Leung et al, 2011b; Orom et al, 2008). Experimental data with miRNA-binding sites located in coding regions suggest a less robust regulation as compared with the $3^{\prime}$ UTR (Easow et al, 2007; Gu et al, 2009).

There are several outcomes of the miRNA/RISC binding to target mRNAs that predominantly include mRNA destabilization and degradation as well as translational repression (reviewed in detail in Fabian et al, 2010). Intriguingly, there are some instances in which association of the miRNA with the $3^{\prime}$ or $5^{\prime}$ UTR causes target mRNA translational activation rather than repression (Henke et al, 2008; Orom et al, 2008; Vasudevan et al, 2007). In general, the targeting of the $3^{\prime}$ UTR mRNA by a miRNA results in the modest repression of mRNA expression within the range of maximal 1.5-2-fold (Guo et al, 2010; Selbach et al, 2008). mRNA degradation is thought to occur in discrete cytoplasmic foci known as processing-bodies (p-bodies) and related stress granules (Franks and Lykke-Andersen, 2008; Kedersha et al, 2005; Sheth and Parker, 2003). These specialized granules contain a fraction of the Ago proteins and are sites of RNA storage and catabolism (Franks and Lykke-Andersen, 2008; Leung et al, 2006; Sheth and Parker, 2003; Yekta et al, 2004). They contain a high concentration of proteins involved in mRNA degradation including decapping (DCP1/2) and deadenylating enzymes (Franks and Lykke-Andersen, 2008). It has been shown that Ago proteins upon mRNA target binding can localize to p-bodies (Bhattacharyya et al, 2006; Liu et al, 2005b). Besides Ago proteins and mRNA deadenylation, decapping, and degradation enzymes, p-bodies (also known as GW bodies) are enriched for members of the GW182 protein family (Eystathioy et al, 2002, 2003). GW182 proteins are proteins that are crucially involved in miRNA-induced target mRNA repression. There are three mammalian isoforms of the GW182 protein in mammals, TNRC6-A, -B, and -C (Behm-Ansmant et al, 2006; Jakymiw et al, 2005; Liu et al, 2005a,b; Sen and Blau, 2005). The direct interaction of Ago2 with GW182 via their GW domain is of key importance for miRNA-mediated silencing. Disruption of this interaction, by point mutation or peptide competing, negates the silencing ability of Ago (Behm-Ansmant et al, 2006; Eulalio et al, 2008; Jakymiw et al, 2007; Liu et al, 2005a; Rehwinkel et al, 2005). GW182 binding to Ago at the miRNA-bound $3^{\prime}$ UTR site of a target gene creates a docking platform through which deadenylase complexes can gain access to the Poly(A) tail of the targeted mRNA. GW182 directly recruits the CCR4-NOT deadenylase complexes that leads to deadenylation and destabilization of the miRNA-targeted transcript (Behm-Ansmant et al, 2006; Braun et al, 2011; Chekulaeva et al, 2011; Fabian et al, 2011).

In addition to its function in mRNA degradation, GW182 has been implicated in control of translation repression. 
GW182 was identified to directly interact with the poly-A binding protein PABP and, by preventing PABP/eIF4Gdependent loop formation, contributes to the repression of translational initiation. In addition to inhibition of closedloop formation, the mechanism for miRNA-dependent regulation of translational initiation includes repression of $5^{\prime}$ cap recognition, $40 \mathrm{~S}$ subunit recruitment, and the repression of $60 \mathrm{~S}$ subunit joining and inhibition of $80 \mathrm{~S}$ complex assembly (Humphreys et al, 2005; Pillai et al, 2005). Moreover, miRNAs have been demonstrated to interfere with ribosome elongation, inducing ribosomedrop-off or facilitation proteolysis of the nascent polypeptides (reviewed in Fabian et al, 2010).

Recent studies have addressed the relative contribution of these various gene-silencing mechanisms. Through the comparison of the degree of mRNA stabilization/destabilization and target protein levels in cells that had decreased or increased miRNA dosage, the conclusion was drawn that the degree of change observed in protein levels of a miRNAtarget gene is directly proportional to the degree in target mRNA alteration (Guo et al, 2010; Selbach et al, 2008). Therefore, the authors conclude that the mRNA destabilization pathway is the primary silencing mechanism. Although these elegant and quantitative studies were performed in cell lines and ex vivo isolated granuocytes, it is possible that each cell type may harness a distinct or a combination of silencing mechanism(s) tailored to it own cell biological requirements.

Another important consideration in the appreciation of miRNA-mediated gene silencing is that a given miRNA can have hundreds of target mRNAs (Friedman et al, 2009; Krek et al, 2005; Lim et al, 2005). Sequencing analysis of Ago2-associated miRNAs and mRNAs from developing mouse brain confirmed the magnitude of miRNA/mRNA target regulation in the brain in vivo (Chi et al, 2009). Of course, some targets can/will be of greater biological importance than others. Thus, miRNAs have the ability to simultaneously regulate several genes in one/multiple given biological pathway. In addition, several miRNAs can converge on an individual target transcript (Bartel, 2004). The stoichiometry by which miRNA/RISC induces silencing of transcript is thought to require several RISC-binding events to induce the most efficient silencing (Pillai et al, 2005). Therefore, miRNAs function sub-stoichiometrically and thus the relative expression of a specific miRNA and its target at a given time point in a distinct spatial compartment may determine the propensity of mRNA silencing.

This might be of particular importance in neurons, where neuronal activity-induced gene expression changes can lead to a sudden shift in target mRNA expression during neuronal activation as compared with the basal state. The profile of suppressed target mRNAs as well as the functional outcome of miRNA/mRNA regulation in individual neurons might differ markedly between the various levels of neuronal activation. The changes in target mRNA suppression could be of particular functional importance in cases where a larger pool of target mRNAs is competing for a limited amount of miRNAs within distinct compartments such as synapses. Moreover, the targets of a specific miRNA that is present in the neuronal soma as well as in the dendritic/axonal compartment could differ considerably between compartments depending on the specific target mRNAs expressed. The elucidation of the spectrum of miRNAs/mRNA regulation in specific neurons within the different compartments at various levels of neuronal activity will depend on the analysis of miRNA/mRNA regulation in a cell type-specific, compartment-specific, and activity-dependent fashion.

\section{Regulation of the miRNA Pathway}

The miRNA pathway is subject to transcriptional, posttranscriptional, and posttranslational regulation, and the physiological significance of it is only beginning to be understood. These regulations not only intersect the protein components of the pathway, but also the RNA components inclusive of the pre-miRNAs. The most obvious strategy to regulate the output of the pathway is to alter the content or dosage of miRNAs within RISC. Similar to coding genes, miRNA-encoding loci are transcriptionally regulated and can be subject to vast changes in activity in response to either developmental or environmental cues. The regulation of gene expression programs by neuronal activity is an essential mechanism for neuronal adaptation to environment changes. Neuronal activity plays an essential role in regulating synaptic strength and connectivity of adult neurons. Similar to the activity-induced activation of protein-coding gene transcription, the transcriptional activation of several neuronal miRNAs, such as the miR-132/ 212 and the miR-379-410 clusters, depends on the neuronal activity-induced transcription factors CREB and MEF2, respectively (Impey et al, 2010; Nudelman et al, 2010; Vo et al, 2005). miR-132 as well as miR-134, which originates from the miR-379-410 cluster, have been shown to be among several miRNAs that are critically involved in activity-dependent dendritic remodeling and synapse maturation by targeting p250RhoGAP and Pum2/Limk1, respectively (Christensen et al, 2010; Fiore et al, 2009; Hansen et al, 2010; Schratt et al, 2006; Wayman et al, 2008).

Although the transcriptional regulation of the miRNAencoding loci has long been appreciated, it has recently come to light that that miRNA turnover is an equally important and highly regulated event in neurons. The halflife among neuronal miRNAs can differ significantly. The first indication of differential miRNA stability in neurons came from studies of Dicer-deficient adult neurons. Upon ablation of Dicer in postnatal, differentiated Purkinje cells in the mouse cerebellum, numerous miRNAs remained expressed at wild-type levels for weeks/month after the loss of Dicer (Schaefer et al, 2007). Although some miRNAs such as miR-124a became undetectable within days after the deletion of Dicer, other miRNAs such as miR-138 remained expressed at almost wild-type levels until the death of the neuron. Differential regulation of miRNA stability and 
turnover rates in a neuronal cell type-specific manner could be a potent and generally applied mechanism controlling distinct neuron functions. Notably, miRNA turnover in neurons appears to be activity dependent. Exposure of Aplysia sensory neurons to the neurotransmitter serotonin leads to the rapid downregulation of miR-124 and miR-184 (Rajasethupathy et al, 2009). Moreover, recent studies identified a subpopulation of miRNAs in the mouse retina with light-dependent turnover rates of $<60 \mathrm{~min}$, as well as miRNAs whose half-life depends on neuronal activity in the hippocampus. Although many miRNAs including miR-124, miR-29c, and let-7b in the mouse retina are stably expressed during light/dark changes, the expression levels of a specific subgroup of miRNAs such as miR-183/96/182, miR-204, and miR-211 cycle according to the different light levels. Their rapid turnover during light/dark transitions are driven by transcriptional activation and active decay, respectively (Krol et al, 2010). Similarly, activation of in vitro-cultured mouse neurons by the neurotransmitter glutamate induced the reduction of several miRNAs including miR-124, miR128, miR-134, and miR-138, whereas the expression of other miRNAs such as miR-16, miR-25, miR-23b, and miR-132 remained unchanged (Krol et al, 2010). Recent studies on miRNA stability and expression using nonneuronal in vitro cultures identified a group of miRNAs, including miR-21, $-29 b,-34 a,-141,-200 a$, and $-301 a$, which are rapidly downregulated upon loss of cell adhesion without changing preor pri-miRNA expression levels (Kim et al, 2011). Although these data clearly show that cellular activation can directly affect miRNA stability, the pathways involved in mature miRNA degradation remain still largely unknown.

Posttranscriptional regulation of miRNA expression at the level of cytosolic pre-miRNA degradation has recently been discovered in human cells. Whereas overexpression of MCPIP1, a CCCH-type zinc-finger protein with RNAbinding potential, was found to decrease ectopically and endogenously expressed miRNAs, MCPIP1 knockdown elevated the levels of several miRNAs such as miR-2, -26a, $-107,-182,-146 a,-17-5 p$, and $-135 b$ in HepG2 cells (Suzuki et al, 2011). The MCPIP1-dependent changes in miRNA expression levels depend on its ribonuclease activity, leading to cleavage of the terminal pre-miRNA loop and pre-miRNA degradation. Regulation of pre-miRNA stability via stem loop cleavage makes MCPIP1 a direct functional antagonist to Dicer during miRNA biogenesis. Notably, the authors show that MCPIP1-dependent degradation of pre-miRNAs belonging to the let-7 family can be prevented by the presence of another RNA-binding factor, lin-28, that specifically recognizes the terminal loop of let-7 premiRNAs and thereby appears to protect them from cleavage (Suzuki et al, 2011). These results indicate the existence of complex regulatory mechanism involving various RNAbinding factors that can antagonize each other functions and thereby control pre-miRNA processing and degradation.

The posttranscriptional modification of pre-miRNAs is another strategy that has recently been described. Lin-28 and Tut4 have been shown to negatively regulate let-7
miRNA dosage in a variety of organisms (Hagan et al, 2009; Heo et al, 2009; Lehrbach et al, 2009). Lin-28 recognizes a conserved motif in the hairpin of many let-7 pre-miRNAs (Heo et al, 2009) and recruits the poly-uridylating enzyme Tut4. Poly-uridylation targets the pre-miR for degradation, resulting in the reduction of the corresponding mature miRNA (Hagan et al, 2009; Heo et al, 2009; Lehrbach et al, 2009). To date, this mechanism has only been observed for members of the ubiquitously expressed let-7 miRNA family. This miRNA family is encoded by 11 loci in mice and, because of functional redundancies, the precise contribution to neuronal biology has not yet been genetically addressed. However, there is overwhelming evidence that let-7 miRNAs, which are not only ubiquitously but also abundantly expressed, function as a tumor-suppressor mechanism. In addition to regulating pre-let-7, Tut4 was recently shown to regulate mature miRNA activity again through poly-uridylation (Jones et al, 2009). Conversely, the addition of a $3^{\prime}$ adenosine after Dicer processing by the cytoplasmic poly(A) polymerase GLD-2 has been shown to stabilize miR-122 in liver cells (Katoh et al, 2009). Thus, the addition of $3^{\prime}$ nucleotides has been described that defines a cellular mechanism by which miRNA half-life or activity may be regulated.

Regulating mature miRNA activity rather than its stability is another recently described mechanism that could play an important physiological role in neurons. Artificial miRNA sponges, RNA sequences containing several consecutive binding sites for one specific miRNA that can function as high-affinity decoy targets, have been developed recently as a potent tool to inhibit miRNA activity in cells without changing miRNA expression levels (Ebert et al, 2007). Given the ability of mRNA-based miRNA sponges to specifically inhibit miRNA function, the authors speculated that nature itself might have invented a similar mechanism to regulate miRNA activity (Ebert and Sharp, 2010). Recent data confirmed the existence of endogenous sponges such as the TPSI family of noncoding RNAs in plants (FrancoZorrilla et al, 2007), Herpesvirus saimiri U-rich RNAs (HSURs) in viruses (Cazalla et al, 2010), as well as the PTENP1 pseudogene in mammals (Poliseno et al, 2010). Indeed, a class of long noncoding RNAs that act as miRNA sponges were identified and termed competing endogenous RNAs (ceRNAs) with functions in muscle differentiation and tumor suppression (Cesana et al, 2011; Karreth et al, 2011; Tay et al, 2011). Moreover, it is possible that actual miRNA-target genes by themselves might function as endogenous sponges and can actively regulate miRNA activity. For example, expression of the $3^{\prime}$ UTRs of prohibitin, Pea-15, and troponin 1 had been previously described to influence proliferation and differentiation of cancer and muscle cells, respectively (Jupe et al, 1996; Rastinejad et al, 1993; Tsukamoto et al, 2000). Several of the predicted miRNA-target genes contain not one but multiple, consecutive miRNA-binding sites within their $3^{\prime} U T R s$. For example, the $3^{\prime}$ UTR of the onecut homeobox 2 transcription factor (Onecut2) appears like bona fide naturally designed 
miR-9 sponge by possessing a total of 13 individual miR-9binding sites within its sequence (as predicted by TargetScan; Lewis et al, 2005).

Because of the existence of spatially separated zones of mRNA translation in neurons, the expression of endogenous miRNA sponges followed by local sequestration of miRNAs could have major consequences on local miRNAtarget gene expression within the specific neuronal compartments. Although the constitutively expression of a miRNA sponge could fine-tune the activity of miRNA regulation and/or affect the profile of the target pool, activity-dependent induction of miRNA sponge expression could cause a sudden release of target mRNA suppression from specific miRNAs followed by their translation activation.

\section{MIRNA EXPRESSION IN THE BRAIN}

Almost $50 \%$ of all identified miRNAs are expressed in the mammalian brain (Krichevsky et al, 2003; Lagos-Quintana et al, 2002; Landgraf et al, 2007; Miska et al, 2004; Sempere et al, 2004; Shao et al, 2010). These miRNAs appear to be differentially distributed between distinct brain areas in mammals as well as in evolutionary lower species such as zebrafish. In addition to brain region or neuron typespecific expression differences (Bak et al, 2008; Landgraf et al, 2007; Olsen et al, 2009; Wienholds et al, 2005), neurons also display differential intraneuronal miRNA compartmentalization (Cougot et al, 2008; Lugli et al, 2008; Mollet et al, 2008; Pichardo-Casas et al, 2012; Siegel et al, 2009). Several miRNAs such as miR-125b, miR-128, miR-132, miR-134, and miR-139 are enriched in synapses or dendrites as compared with the perinuclear cell soma (Cougot et al, 2008; Edbauer et al, 2010; Lugli et al, 2008; Mollet et al, 2008; Pichardo-Casas et al, 2012; Schratt et al, 2006; Siegel et al, 2009). Moreover, miRNAs specifically enriched in the distal axon of sympathetic neurons in the rat have been recently isolated (Natera-Naranjo et al 2010). The enrichment of specific miRNAs within the axonal and dendritic compartments indicates their potentially unique role in control of local protein expression, synapse maturation, and/or function. Their synaptic localization in combination with their activity-dependent regulation link miRNAs to the adaptive processes of neural circuit formation and function. Recent data on the role of synaptic miRNAs and their target gene networks have revealed their importance for synapse development and physiology (reviewed in great detail in Corbin et al, 2009; Konecna et al, 2009; Kosik, 2006; Schratt, 2009; Siegel et al, 2011; Smalheiser and Lugli, 2009). The mechanisms that contribute to specific enrichment of miRNAs within synapses, dendrites, and axons remain unknown, but are likely to involve RNA-binding proteins that deliver or anchor miRNAs to particular neuron areas. Indeed, several brain-enriched miRNAs, including miR-125b, miR-128, and miR-132, have been found in association with FMRP, a RNA-binding protein that localized into dendrites and is known for its important role in the regulation of local protein translation (Edbauer et al, 2010; Schratt et al, 2006). Furthermore, the presence of RISC in the pre- and postsynaptic neuronal compartments underscores the ability of miRNAs to not only migrate to the axonal and dendritic sites of synapses, but also be potentially generated locally from pre-miRNAs (Ashraf et al, 2006; Banerjee et al, 2009; Barbee et al, 2006; He et al, 2012; Hengst et al, 2006; Lugli et al, 2005, 2008).

The expression levels of miRNAs in neurons vary significantly. Some miRNAs such as let-7, miR-124, and miR-128 are expressed at very high copy numbers (up to 30 000-50000 copies/neuron) (Lim et al, 2003; Raymond et al, 2005), whereas the levels of other brain expressed miRNAs can be as low as 1-2 copies/cell as deduced from the analysis of the total brain tissue or neuronal cell culture extracts. The latter approaches of RNA analysis ignore the potential highly specific distribution of miRNAs within different neuronal population and could lead to misleading conclusions about potential miRNA significance in vivo. In situ analysis of miRNAs in zebrafish and mouse brain points not only to neuron-type diversity of miRNA distribution, but also potential interneuronal diversity of miRNA expression within the same brain areas (Pena et al, 2009; Schaefer et al, 2007; Wienholds et al, 2005). The exact estimate of individual miRNA expression levels and patterns at a single neuron resolution will provide the most valuable information about the possible role of miRNAs in establishing the functional neuron diversity. In support of the neuron-specific diversity of miRNA expression levels, single-cell analysis of the pan-neuronal-specific miRNA, miR-9, in mice revealed significant differences in miR-9 copy number expression between a striatal and a magnocellular neuron (Pietrzykowski et al, 2008).

The putative interneuronal miRNA diversity might be rooted in the multiplicity of genes encoding a single miRNA species. Approximately $10 \%$ of the $\sim 1500$ mature miRNAs annotated in humans derive from more than one gene (www.mirbase.org; Griffiths-Jones, 2006). Notably, many of the brain-enriched miRNAs are encoded by multiple genes. Three highly abundant neuron-specific miRNAs, mir-124, miR-7, and miR-9, as well as the highly abundant but rather ubiquitously expressed miRNA, let-7a, are each encoded by three different genes in humans (Griffiths-Jones, 2006). The brain-enriched miR-128, miR-129, miR-133a, miR-138, miR-153, miR-181a, miR-181b, miR-218, and miR-219, as well as the highly abundant but rather ubiquitously expressed let7-f, miR-16, miR-26a, miR30c, miR-101, miR-103a, miR-103b, and miR-125b are encoded by two independent gene loci (Griffiths-Jones, 2006). Moreover, in most of the cases the genes that encode a single miRNA species are located on different chromosomes. The multiplicity of genes encoding a single miRNA species may have several reasons. The expression of miRNAs from different chromosomes might represent a back-up mechanism that ensures the expression of essential miRNAs in case of deleterious mutations to one of the miRNA-encoding 
alleles. Alternatively, multiplicity of miRNA-encoding genes may be required to keep the miRNA expression at levels that could not be achieved by transcription from a single miRNA gene. It is also possible that multiplicity of miRNAcoding genes supports interneuronal diversity of miRNA expression. Similar to protein-coding genes that are expressed at different levels in functionally distinct neurons, the transcription of individual miRNA-encoding genes may differ significantly between individual neurons, thus contributing to the neuron-specific pattern and levels of miRNA expression. This putative mechanism may also enable epigenetic control of miRNA expression through signal-dependent chromatin changes of its (host) genes. The possibility of the described scenario is supported by differential contribution of the two individual miR-128 genes to the expression of the brain-enriched and highly abundant miR-128. The miR-128 is encoded by miR-128-1 and $m i R-128-2$ genes located in the intronic region of the R3hdm1 gene on chromosome 2 and the Arpp21 gene on chromosome 3, respectively. The expression of miR-128-1 from the $R 3 h d m 1$ intron and mir-128-2 from the Arpp21 intron is evolutionary conserved among many vertebrates from humans to mice and zebrafish (Griffiths-Jones, 2006). Using genetic selective ablation of the miR-128-1 and -2 genes in mice, we found that the miR-128-1 gene is responsible for only $20 \%$ of the total mature miR- 128 expressed in neurons, whereas miR-128-2 generates the remaining $80 \%$ (unpublished data from Anne Schaefer and Chan Lek Tan). The described asymmetry in individual miR-128 gene contribution to the neuronal miR-128 pool may contribute to the establishment of a miRNA controlled regulatory loop similar to those observed in C. elegans. There, one of the more complex regulatory feedback mechanisms controls the development of left/right asymmetry of the 'ASE' chemosensory neurons in the worms. The asymmetric expression profiles of ASE left (ASEL) and ASE right (ASER) neurons is governed by the expression of two miRNAs, lys-6 and miR-273, that target distinct transcription factors controlling left $v s$ right ASE neuron lineage-specific chemosensory receptor expression. Whereas miR-273 is induced by the transcription factor COG-1 in ASER neurons and suppresses the ASES neuronspecific transcription factor DIE-1, ASES neurons express DIE-1 that induces lys-6, which suppresses the ASER neuron inducing COG-1, thereby lacks induction of miR-273 expression, which obliterates miR-273-induced repression of DIE-1 (Johnston and Hobert, 2003).

Neuron-specific miRNA expression can be regulated not only at the transcriptional but also at posttranscriptional levels that involve differential pri- and pre-miRNA processing. Although the pre-miR-138 is expressed ubiquitously, the expression of the mature miR-138 is limited largely to neurons (Obernosterer et al, 2006). This discrepancy between tissue specificity of pre-miRNA and mature miRNA expression implies the existence of a mechanism that allows neuron-specific regulation of Dicer or Ago2 activities in a miRNA- and cell type-specific fashion. Differential activation of Dicer had been reported in early studies that revealed neuronal activity-induced stimulation of Dicer activity at the synapse (Lugli et al, 2005). Another possible mechanism to regulate miRNA expression in neurons may involve posttranslational modification of the RISC complex that contributes to the processing of numerous miRNA species (O'Carroll et al, 2007; Schaefer et al, 2009). Several components of the RISC complex have been shown to be posttranslationally modified. TRBP is phosphorylated on several serine residues via the MAP kinase pathway with a positive impact on TRBP stability, resulting in increased Dicer levels (Paroo et al, 2009). Recent studies have shown that Ago2 is subjected to several posttranslational modifications ranging from prolyl hydroxylation, phosphorylation, and ubiquitination to poly ADP ribosylation (Leung et al, 2011a; Qi et al, 2008; Rudel et al, 2010; Rybak et al, 2009; Zeng et al, 2008). Phosphorylation of Ago2 by MAPKAP kinase 2 (MK2) implies a possibility of signal-dependent control of miRNA biogenesis and miRNA-mediated gene silencing (Zeng et al, 2008). In neurons, activation of MAP kinase occurs in response to various signals including growth factors and has been linked to the control of gene expression patterns in specific types of neurons.

In support of this concept, the protein Moloney leukemia virus 10 (Mov10), the mammalian homolog of the Drosophila RISC component Armitage, localizes to the synapse in hippocampal rat neurons and is degraded upon neuronal activation (Banerjee et al, 2009). Activity-induced degradation of Mov10 was consequently shown to release miR-138 mediated suppression of several neuroplasticityregulating genes including CamkII, Limk1, and Lypla1 (Banerjee et al, 2009).

It is plausible that RISC activity and the miRNAs controlled by it are a central part of the regulatory signaling network that adjusts neuron transcriptional homeostasis to the environmental signals.

\section{miRNAs AND BRAIN PHYSIOLOGY}

The first evidence for the essential role of miRNAs in brain physiology has been generated by studies of the nervous system development in Dicer-deficient zebrafish. Because of the lack of Dicer-dependent pre-miRNA processing, the zebrafish fails to produce any mature miRNAs. Lack of mature miRNAs caused severe malformation in the central nervous system, as well as in some other organs (Giraldez et al, 2005). Similarly, engineered Dicer deficiency in olfactory progenitor neurons in mice and zebrafish arrested the terminal differentiation of progenitor cells into mature olfactory neurons (Choi et al, 2008). The brain malformations or defective olfactory neuron differentiation caused by Dicer deficiency appears, in each case, to reflect the key role of one specific miRNA subclass. The abnormal brain morphology including impaired brain ventricle and midbrain/hindbrain boundary formation caused by Dicer 
deficiency in zebrafish could be rescued by re-introducing miRNAs of the miR-430 family (Giraldez et al, 2005). Similarly, olfactory defects caused by Dicer deficiency likely reflect a key role of the mir-200 miRNA family in the development of these neurons (Choi et al, 2008).

The selective role of individual miRNAs in the regulation of neuron function and survival has been further supported by studies of Dicer-deficient adult neurons. Deficiency in Dicer in differentiated neurons in the mouse cerebellum revealed a critical role of miRNAs in neuronal survival (Schaefer et al, 2007). Selective loss of Dicer in Purkinje cells initiated a slow neurodegenerative process associated with Purkinje cell death and the development of ataxia 2-3 months after the deletion of Dicer gene. The essential role of miRNAs in adult neuron survival was confirmed by ablation of Dicer in dopaminergic neurons, striatal D2 neurons, and excitatory forebrain neurons (Davis et al, 2008; Kim et al, 2007; Schaefer et al, 2010).

Despite the lack of Dicer, numerous miRNAs remained expressed at wild-type levels until the onset of Purkinje cell death (Schaefer et al, 2007). The differences in miRNA decay were unrelated to miRNA copy numbers. Although miR-124a, the most abundant neuron-specific miRNA, was among the first miRNAs to disappear following Dicer deficiency, less abundant miRNAs were still detectable. These studies suggested differential stability of miRNAs in adult neurons. It also suggested that the less stably expressed miRNAs, such as miR-29a, miR-29b, miR-30c, miR-101, miR-103, miR-125b, and miR-181a, are likely regulators of neuronal survival, whereas the more stably expressed miRNAs, including miR-134, miR-138, miR-143, miR-149, miR-212, and miR-329, are regulators of the specific Purkinje cell functions that remained electrophysiologically and behaviorally unperturbed until the onset of Purkinje cell death (Schaefer et al, 2007).

Differential dependence of individual miRNA species on Ago2 was successfully employed to identify miRNAs that may contribute to neuron dopamine responses and addiction. In these studies, adult neurons were rendered deficient for the Ago2 protein that contributes both to miRNA generation and mRNA target suppression. Ago2 is involved in the processing of miRNAs from their precursors (O'Carroll et al, 2007). This function of Ago2 contributes differential to individual miRNA generation, where only a fraction of miRNAs appears to be affected by the loss of Ago2 in nonneuronal cells (O'Carroll et al, 2007) as well as in neurons (Schaefer et al, 2010). In contrast to the deficiency of Dicer, loss of Ago2 in neurons has no obvious impact on neuronal survival and mice well-being. However, responses of neurons to neurotransmitters appear to require Ago2. Loss of Ago2 in dopamine receptor 2-expressing (D2) neurons in the striatum played a key role in cocaine addiction (Schaefer et al, 2010). In contrast to control mice, which develop a strong dependence on cocaine, mice that lack Ago2 in D2 neurons do not become addicted. Opposite to the loss of Ago2, loss of either Ago1, 3 , or 4 was not associated with any behavioral abnormalities nor did it lead to any changes in mRNA or miRNA expression in the brain regions investigated (Schaefer et al, 2010).

Overall, the studies of Dicer- and Ago2-deficient neurons in the postnatal brain point toward a role of miRNAs as tuners of neuron function rather than gate-keepers of neuronal differentiation as suggested by earlier studies of neuron-specific miR-124 during brain development. This miRNA becomes strongly upregulated during neuronal differentiation from neuronal stem cells (NSCs) to differentiated neurons (Krichevsky et al, 2003). Before the neuronal lineage commitment, expression of miR-124 gene is repressed by the transcriptional repressor RE1-silencing transcription factor (REST) (Conaco et al, 2006). REST is expressed in all nonneuronal cells where it inhibits neuronspecific gene expression. REST recruits histone deacetylases and methyl CpG-binding protein $\mathrm{MeCP} 2$ to the miR-124 gene promoter and silences its transcription. Upon activation of NSC differentiation into neurons, REST expression is downregulated and miR-124 gene expression is induced (Conaco et al, 2006). The upregulation of miR-124 during the developmental switch between progenitor proliferation and neuronal fate commitment reflects the essential role of miR-124 in suppression of various nonneuronal targets that need to be removed in order to progress to the next stage (Conaco et al, 2006). Moreover, miR-124 induces the expression of neuron-specific mRNA splice variants by directly suppressing PTBP1, a repressor of alternative premRNA splicing that is expressed predominantly in nonneuronal cells (Makeyev et al, 2007). The ability of miR-124 to control not only the expression of one or two target genes but entire neuronal gene expression pattern of more than 100 genes was demonstrated by the ectopic expression of miR-124 in Hela cells. Upon miR-124 expression, Hela cells changed their specific gene expression pattern into a neuronal pattern (Lim et al, 2005). The mechanism of the miR-124-mediated switch from early progenitors to neurons relies on miR-124-mediated suppression of the BAF53a component of the ATP-dependent chromatin remodeling SWI/SNF complex. The absence of BAF53a and its concomitant replacement by BAF53b promotes termination of cell division and differentiation in nondividing neurons (Yoo et al, 2009, 2011). Another brain-specific and highly abundantly expressed miRNA, mir-9, is important for the progression of neurogenesis and in organization of the midbrain/hindbrain boundary during brain development (Krichevsky et al, 2003; Leucht et al, 2008). In support of the key role of miR-124 and miR-9 in neuronal lineage commitment and differentiation, ectopic expression of miR-124 and miR-9 in fibroblasts resulted in these cells reprogramming into neurons (Yoo et al, 2011).

Deficiency of Dicer or Ago2 revealed not only a potent role of miRNAs in adult neuronal function, but also ruled out miRNAs as essential keeper of neuronal differentiation in the adult brain. The Dicer-deficient adult Purkinje cells could linger for weeks or even months without any visible alteration to their morphology or their electrophysiological properties. GFP-based lineage tracing of Dicer-deficient 
Purkinje cells confirmed the lack of de-differentiation or migration of these cells between the time of Dicer deletion $\sim 3-4$ weeks postnatally and cell degeneration at $\sim 3$ months of age (Schaefer et al, 2010). These data might suggest that the significance of miR-124, miR-9, and other miRNAs controlling neuronal differentiation is restricted to the developing brain. However, these miRNAs remain abundantly expressed in adult neurons, which suggest a potential functional switch between their role and/or target pool during brain development as compared with the postnatal brain. Recent work revealed an important role of miR-9 in splice variants expression regulation of the largeconductance calcium-and voltage-activated potassium channel (BK) in adult mouse brain (Pietrzykowski et al, 2008). Alcohol consumption in adult mice causes a rapid, $\sim 2$-fold increase in miR-9 levels in neurons in the supraoptic nucleus and the striatum followed by a consecutive suppression of BK splice variants that contain $3^{\prime}$ UTR miR-9-binding sites. The reorganization of BK splice variants toward a 'miR-9 insensitive' BK channel isoform profile is associated with changes in alcohol responsiveness of the BK channel (Pietrzykowski et al, 2008). These data indicate that developmentally important miRNAs that remain highly expressed in neurons might switch their functional roles from ensuing neuronal differentiation to regulating environmental adaptation of the adult brain.

\section{miRNAs IN NEUROLOGICAL AND PSYCHIATRIC DISEASE}

The potential involvement of miRNAs in initiation and/or progression of neurological diseases is suggested by their complex role in regulation of gene expression in neurons and glia. The results of numerous studies showing changes in miRNA expression levels and patterns during various neurological and psychiatric diseases in humans clearly indicate an involvement of miRNAs in these disorders (reviewed in more depth in Im and Kenny, 2012; Fiore et al, 2011; Olde Loohuis et al, 2012). For example, whereas miR-16, $-30 \mathrm{~b}$, and $-181 \mathrm{~b}$ are found to be significantly upregulated in the cortex of schizophrenia patients, miR132 was significantly downregulated in the cortex of schizophrenia patients as well as in patients suffering from Autism spectrum disorders (Abu-Elneel et al, 2008; Beveridge and Cairns, 2012; Beveridge et al, 2008; Miller et al, 2012; Perkins et al, 2007). Patients and mice suffering from Huntington's disease displayed downregulation of several miRNAs including, miR-9/9*, $-17,-29 \mathrm{a} / \mathrm{b},-124,-132$, -196a, -222, -330, -485, and -486 (Johnson et al, 2008; Packer et al, 2008), whereas miR-9 and miR-128 were found to be upregulated in the CNS of patients with Alzheimer's disease as compared with their age-matched control samples (Lukiw, 2007).

Trisomy 21, also known as Down Syndrome (DS), is caused by a triplication of the human chromosome 21 and is associated with cognitive impairments and congenital heart defects. The expression levels of the five miRNAs encoded on chromosome 21, let-7c, miR-99a, -125b-2, -155, and -802 , were found to be increased in the fetal brain and heart of patients with DS (Kuhn et al, 2008). However, the exact mechanism of how triplication of chromosome 21 including the altered expression of the five miRNAs leads to the manifestations of the disease remains unknown.

Individuals suffering from the DiGeorge syndrome, caused by a 22q11.2 microdeletions that includes the DGCR8 gene, show behavioral and cognitive deficits and are at high risk of developing schizophrenia. A mouse model with a chromosomal deficiency spanning a segment syntenic to the human 22q11.2 locus revealed a specific subset of brain miRNAs, including miR-134, that were affected by the haploinsufficiency of DGCR8 (Stark et al, 2008).

Although these data clearly demonstrate that miRNA expression in the human brain is affected during neurological and psychiatric diseases, the interpretation of the observed changes in miRNA expression as a cause or a consequence of specific neuronal alteration in these disorder remains challenging.

Evidence to support the physiological significance of a miRNA/mRNA target interaction in human neurons could come from the discovery of disease-associated mutations/ polymorphisms within the miRNA or the miRNA-binding sites of target genes that will affect miRNA expression and/or target gene suppression in neurons (Sun et al, 2009). One example that supports this notion includes a single mutation in the $3^{\prime}$ UTR of the SLITRK1 gene that leads to a disruption of its $3^{\prime} \mathrm{UTR}$ miR-189-binding site and is associated with the development of Tourette syndrome and obsessive-compulsive disorders (Abelson et al, 2005). However, the recent advances in mutation analysis of human disease by whole-genome sequencing and the inclusion of the $3^{\prime}$ and $5^{\prime}$ UTRs as well as miRNAs and long-noncoding RNAs genes should help to reveal the actual contribution of miRNAs to human disease development. In support of this concept, a recent genome-wide study of schizophrenia-associated gene polymorphism from $\sim 20000$ patient and $>30000$ control samples revealed miR-137 as their strongest novel disease-associated candidate gene (Ripke et al, 2011). Moreover, four of the other identified schizophrenia loci that achieved genome-wide significance within this study contained several miR-137predicted target genes. These data suggest that miR-137dependent gene dysregulation may present a previously unknown etiologic mechanism in the development of schizophrenia (Ripke et al, 2011).

\section{CONCLUSION}

The research on the role of miRNAs in brain function has reached the state where cataloging neuron-expressed miRNAs is shifting toward a mechanistic understanding of individual miRNAs function at the level of individual neurons and/or functionally integrated neuronal circuits. The novel approaches using transgenic mice for the neuron 
type-specific analysis of Ago2-bound miRNA and mRNAs (Chi et al, 2009; He et al, 2012; Schaefer et al, 2010) may facilitate identification of neuron type-specific miRNA targets as well as the specific functional pathways that are targeted by miRNAs in neurons. The analysis of individual miRNA functions will require their inactivation or overexpression within well-defined neuron subpopulations that are characterized by common signaling features and specific physiological function, for example, dopaminergic $v s$ serotonergic neurons. Recent findings show the potent ability of individual miRNAs to control cocaine addiction (Hollander et al, 2010; Im et al, 2010), alcohol tolerance (Pietrzykowski et al, 2008), to regulate fear extinction (Lin et al, 2011), and circadian rhythm (Cheng et al, 2007) in mice (for a more detailed review on specific miRNA function in the nervous system, please read Fiore et al, 2011; Im and Kenny, 2012; Olde Loohuis et al, 2012). These specific functions of miRNAs could be potentially used to develop RNA-based approaches for the therapy of neurological and psychiatric disorders.

\section{ACKNOWLEDGEMENTS}

We recognize and apologize to all of our colleagues whose work could not be acknowledged because of space limitations. This work was funded by the NIH Grant DA025962 and USAMRMC Grant W81XWH-09-1-0095 to A Schaefer. A Schaefer is a recipient of the 2010 NARSAD Young Investigator Award and named Chrissy Rossi fellow.

\section{DISCLOSURE}

The authors declare no conflict of interest.

\section{REFERENCES}

Abelson JF, Kwan KY, O’Roak BJ, Baek DY, Stillman AA, Morgan TM et al (2005). Sequence variants in SLITRK1 are associated with Tourette's syndrome. Science 310: 317-320.

Abu-Elneel K, Liu T, Gazzaniga FS, Nishimura Y, Wall DP, Geschwind DH et al (2008). Heterogeneous dysregulation of microRNAs across the autism spectrum. Neurogenetics 9: 153-161.

Alisch RS, Jin P, Epstein M, Caspary T, Warren ST (2007). Argonaute2 is essential for mammalian gastrulation and proper mesoderm formation. PLoS Genet 3: e227.

Ambros V, Horvitz HR (1984). Heterochronic mutants of the nematode Caenorhabditis elegans. Science 226: 409-416.

Ashraf SI, McLoon AL, Sclarsic SM, Kunes S (2006). Synaptic protein synthesis associated with memory is regulated by the RISC pathway in Drosophila. Cell 124: 191-205.

Babiarz JE, Hsu R, Melton C, Thomas M, Ullian EM, Blelloch R (2011). A role for noncanonical microRNAs in the mammalian brain revealed by phenotypic differences in Dgcr8 versus Dicer1 knockouts and small RNA sequencing. RNA 17: 1489-1501.

Babiarz JE, Ruby JG, Wang Y, Bartel DP, Blelloch R (2008). Mouse ES cells express endogenous shRNAs, siRNAs, and other Microprocessor-independent, Dicer-dependent small RNAs. Genes Dev 22: 2773-2785.

Bak M, Silahtaroglu A, Moller M, Christensen M, Rath MF, Skryabin B et al (2008). MicroRNA expression in the adult mouse central nervous system. RNA 14: $432-444$.

Banerjee S, Neveu P, Kosik KS (2009). A coordinated local translational control point at the synapse involving relief from silencing and MOV10 degradation. Neuron 64: 871-884.
Barbee SA, Estes PS, Cziko AM, Hillebrand J, Luedeman RA, Coller JM et al (2006). Staufen- and FMRP-containing neuronal RNPs are structurally and functionally related to somatic P bodies. Neuron 52: 997-1009.

Barik S (2008). An intronic microRNA silences genes that are functionally antagonistic to its host gene. Nucleic Acids Res 36: 5232-5241.

Bartel DP (2004). MicroRNAs: genomics, biogenesis, mechanism, and function. Cell 116: 281-297.

Baskerville S, Bartel DP (2005). Microarray profiling of microRNAs reveals frequent coexpression with neighboring miRNAs and host genes. RNA 11: 241-247.

Behm-Ansmant I, Rehwinkel J, Doerks T, Stark A, Bork P, Izaurralde E (2006). mRNA degradation by miRNAs and GW182 requires both CCR4:NOT deadenylase and DCP1:DCP2 decapping complexes. Genes Dev 20: 1885-1898.

Berezikov E, Chung WJ, Willis J, Cuppen E, Lai EC (2007). Mammalian mirtron genes. Mol Cell 28: 328-336.

Bernstein E, Caudy AA, Hammond SM, Hannon GJ (2001). Role for a bidentate ribonuclease in the initiation step of RNA interference. Nature 409: 363-366.

Beveridge NJ, Cairns MJ (2012). MicroRNA dysregulation in schizophrenia. Neurobiol Dis 46: 263-271.

Beveridge NJ, Tooney PA, Carroll AP, Gardiner E, Bowden N, Scott RJ et al (2008). Dysregulation of miRNA $181 \mathrm{~b}$ in the temporal cortex in schizophrenia. Hum Mol Genet 17: 1156-1168.

Bhattacharyya SN, Habermacher R, Martine U, Closs El, Filipowicz W (2006). Relief of microRNA-mediated translational repression in human cells subjected to stress. Cell 125: 1111-1124.

Bohnsack MT, Czaplinski K, Gorlich D (2004). Exportin 5 is a RanGTP-dependent dsRNA-binding protein that mediates nuclear export of pre-miRNAs. RNA 10: 185-191.

Braun JE, Huntzinger E, Fauser M, Izaurralde E (2011). GW182 proteins directly recruit cytoplasmic deadenylase complexes to miRNA targets. Mol Cell 44: 120-133.

Burroughs AM, Ando Y, de Hoon MJ, Tomaru Y, Suzuki H, Hayashizaki $Y$ et al (2011). Deep-sequencing of human Argonaute-associated small RNAs provides insight into miRNA sorting and reveals Argonaute association with RNA fragments of diverse origin. RNA Biol 8: 158-177.

Cai X, Hagedorn CH, Cullen BR (2004). Human microRNAs are processed from capped, polyadenylated transcripts that can also function as mRNAs. RNA 10: 1957-1966.

Callis TE, Pandya K, Seok HY, Tang RH, Tatsuguchi M, Huang ZP et al (2009). MicroRNA-208a is a regulator of cardiac hypertrophy and conduction in mice. J Clin Invest 119: 2772-2786.

Cazalla D, Yario T, Steitz JA (2010). Down-regulation of a host microRNA by a Herpesvirus saimiri noncoding RNA. Science 328: 1563-1566.

Cesana M, Cacchiarelli D, Legnini I, Santini T, Sthandier O, Chinappi M et al (2011). A long noncoding RNA controls muscle differentiation by functioning as a competing endogenous RNA. Cell 147: 358-369.

Chaulk SG, Thede GL, Kent OA, Xu Z, Gesner EM, Veldhoen RA et al (2011). Role of pri-miRNA tertiary structure in miR-17 92 miRNA biogenesis. RNA Biol 8: 1105-1114.

Chekulaeva M, Mathys H, Zipprich JT, Attig J, Colic M, Parker R et al (2011). miRNA repression involves GW182-mediated recruitment of CCR4-NOT through conserved W-containing motifs. Nat Struct Mol Biol 18: 1218-1226.

Cheloufi S, Dos Santos CO, Chong MM, Hannon GJ (2010). A dicer-independent miRNA biogenesis pathway that requires Ago catalysis. Nature 465: 584-589.

Chendrimada TP, Gregory RI, Kumaraswamy E, Norman J, Cooch N, Nishikura K et al (2005). TRBP recruits the Dicer complex to Ago2 for microRNA processing and gene silencing. Nature 436: 740-744

Cheng HY, Papp JW, Varlamova O, Dziema H, Russell B, Curfman JP et al (2007). microRNA modulation of circadian-clock period and entrainment. Neuron 54 813-829.

Chi SW, Zang JB, Mele A, Darnell RB (2009). Argonaute HITS-CLIP decodes microRNA-mRNA interaction maps. Nature 460: 479-486.

Choi PS, Zakhary L, Choi WY, Caron S, Alvarez-Saavedra E, Miska EA et al (2008). Members of the miRNA-200 family regulate olfactory neurogenesis. Neuron 57 : 41-55.

Chong MM, Rasmussen JP, Rudensky AY, Littman DR (2008). The RNAselll enzyme Drosha is critical in T cells for preventing lethal inflammatory disease. J Exp Med 205: 2005-2017.

Christensen M, Larsen LA, Kauppinen S, Schratt G (2010). Recombinant adenoassociated virus-mediated microRNA delivery into the postnatal mouse brain reveals a role for miR-134 in dendritogenesis in vivo. Front Neural Circuits 3: 16.

Cifuentes D, Xue H, Taylor DW, Patnode H, Mishima Y, Cheloufi S et al (2010). A novel miRNA processing pathway independent of Dicer requires Argonaute2 catalytic activity. Science 328: 1694-1698.

Conaco C, Otto S, Han JJ, Mandel G (2006). Reciprocal actions of REST and a microRNA promote neuronal identity. Proc Natl Acad Sci USA 103: 2422-2427. 
Corbin R, Olsson-Carter K, Slack F (2009). The role of microRNAs in synaptic development and function. BMB Rep 42: 131-135.

Corcoran DL, Pandit KV, Gordon B, Bhattacharjee A, Kaminski N, Benos PV (2009). Features of mammalian microRNA promoters emerge from polymerase II chromatin immunoprecipitation data. PloS One 4: e5279.

Core LJ, Waterfall JJ, Lis JT (2008). Nascent RNA sequencing reveals widespread pausing and divergent initiation at human promoters. Science 322: 1845-1848.

Cougot N, Bhattacharyya SN, Tapia-Arancibia L, Bordonne R, Filipowicz W, Bertrand $E$ et al (2008). Dendrites of mammalian neurons contain specialized P-body-like structures that respond to neuronal activation. J Neurosci 28: 13793-13804

Czech B, Hannon GJ (2011). Small RNA sorting: matchmaking for Argonautes. Nat Rev Genet 12: 19-31.

Davis TH, Cuellar TL, Koch SM, Barker AJ, Harfe BD, McManus MT et al (2008). Conditional loss of Dicer disrupts cellular and tissue morphogenesis in the cortex and hippocampus. J Neurosci 28: 4322-4330.

Denli AM, Tops BB, Plasterk RH, Ketting RF, Hannon GJ (2004). Processing of primary microRNAs by the Microprocessor complex. Nature 432: 231-235.

Diederichs S, Haber DA (2007). Dual role for argonautes in microRNA processing and posttranscriptional regulation of microRNA expression. Cell 131: 1097-1108.

Doench JG, Sharp PA (2004). Specificity of microRNA target selection in translational repression. Genes Dev 18: 504-511.

Easow G, Teleman AA, Cohen SM (2007). Isolation of microRNA targets by miRNP immunopurification. RNA 13: 1198-1204.

Ebert MS, Neilson JR, Sharp PA (2007). MicroRNA sponges: competitive inhibitors of small RNAs in mammalian cells. Nat Methods 4: 721-726.

Ebert MS, Sharp PA (2010). Emerging roles for natural microRNA sponges. Curr Biol 20: R858-R861.

Edbauer D, Neilson JR, Foster KA, Wang CF, Seeburg DP, Batterton MN et al (2010). Regulation of synaptic structure and function by FMRP-associated microRNAs miR-125b and miR-132. Neuron 65: 373-384.

Ender C, Krek A, Friedlander MR, Beitzinger M, Weinmann L, Chen W et al (2008). A human snoRNA with microRNA-like functions. Mol Cell 32: 519-528.

Eulalio A, Huntzinger E, Izaurralde E (2008). GW182 interaction with Argonaute is essential for miRNA-mediated translational repression and mRNA decay. Nat Struct Mol Biol 15: 346-353.

Eystathioy T, Chan EK, Tenenbaum SA, Keene JD, Griffith K, Fritzler MJ (2002). A phosphorylated cytoplasmic autoantigen, GW182, associates with a unique population of human mRNAs within novel cytoplasmic speckles. Mol Biol Cell 13: 1338-1351.

Eystathioy T, Jakymiw A, Chan EK, Seraphin B, Cougot N, Fritzler MJ (2003). The GW182 protein colocalizes with mRNA degradation associated proteins hDcp1 and hLSm4 in cytoplasmic GW bodies. RNA 9: 1171-1173.

Fabian MR, Cieplak MK, Frank F, Morita M, Green J, Srikumar T et al (2011). miRNA-mediated deadenylation is orchestrated by GW182 through two conserved motifs that interact with CCR4-NOT. Nat Struct Mol Biol 18: 1211-1217.

Fabian MR, Sonenberg N, Filipowicz W (2010). Regulation of mRNA translation and stability by microRNAs. Annu Rev Biochem 79: 351-379.

Fiore R, Khudayberdiev S, Christensen M, Siegel G, Flavell SW, Kim TK et al (2009). Mef2-mediated transcription of the miR379-410 cluster regulates activity-dependent dendritogenesis by fine-tuning Pumilio2 protein levels. EMBO J 28: $697-710$.

Fiore R, Khudayberdiev S, Saba R, Schratt G (2011). MicroRNA function in the nervous system. Prog Mol Biol Trans/ Sci 102: 47-100.

Franco-Zorrilla JM, Valli A, Todesco M, Mateos I, Puga MI, Rubio-Somoza I et al (2007). Target mimicry provides a new mechanism for regulation of microRNA activity. Nat Genet 39: 1033-1037.

Franks TM, Lykke-Andersen J (2008). The control of mRNA decapping and P-body formation. Mol Cell 32: 605-615.

Friedman RC, Farh KK, Burge CB, Bartel DP (2009). Most mammalian mRNAs are conserved targets of microRNAs. Genome Res 19: 92-105.

Giraldez AJ, Cinalli RM, Glasner ME, Enright AJ, Thomson JM, Baskerville S et al (2005). MicroRNAs regulate brain morphogenesis in zebrafish. Science 308 : 833-838.

Glazov EA, Cottee PA, Barris WC, Moore RJ, Dalrymple BP, Tizard ML (2008). A microRNA catalog of the developing chicken embryo identified by a deep sequencing approach. Genome Res 18: 957-964.

Godlewski J, Nowicki MO, Bronisz A, Nuovo G, Palatini J, De Lay M et al (2010). MicroRNA-451 regulates LKB1/AMPK signaling and allows adaptation to metabolic stress in glioma cells. Mol Cell 37: 620-632.

Gregory RI, Yan KP, Amuthan G, Chendrimada T, Doratotaj B, Cooch N et al (2004). The Microprocessor complex mediates the genesis of microRNAs. Nature 432: 235-240.
Griffiths-Jones S (2006). miRBase: the microRNA sequence database. Methods Mol Biol 342: 129-138.

Grishok A, Pasquinelli AE, Conte D, Li N, Parrish S, Ha I et al (2001). Genes and mechanisms related to RNA interference regulate expression of the small temporal RNAs that control C. elegans developmental timing. Cell 106: 23-34.

Gu S, Jin L, Zhang F, Sarnow P, Kay MA (2009). Biological basis for restriction of microRNA targets to the $3^{\prime}$ untranslated region in mammalian mRNAs. Nat Struct Mol Biol 16: 144-150.

Guo H, Ingolia NT, Weissman JS, Bartel DP (2010). Mammalian microRNAs predominantly act to decrease target mRNA levels. Nature 466: 835-840.

Hagan JP, Piskounova E, Gregory RI (2009). Lin28 recruits the TUTase Zcchc11 to inhibit let-7 maturation in mouse embryonic stem cells. Nat Struct Mol Biol 16: 1021-1025.

Hammond SM, Boettcher S, Caudy AA, Kobayashi R, Hannon GJ (2001). Argonaute2, a link between genetic and biochemical analyses of RNAi. Science 293: 1146-1150.

Han J, Lee Y, Yeom KH, Kim YK, Jin H, Kim VN (2004). The Drosha-DGCR8 complex in primary microRNA processing. Genes Dev 18: 3016-3027.

Hansen KF, Sakamoto K, Wayman GA, Impey S, Obrietan K (2010). Transgenic miR132 alters neuronal spine density and impairs novel object recognition memory. PloS One 5: e15497.

He M, Liu Y, Wang X, Zhang MQ, Hannon GJ, Huang ZJ (2012). Cell-type-based analysis of microRNA profiles in the mouse brain. Neuron 73: 35-48.

Hengst U, Cox LJ, Macosko EZ, Jaffrey SR (2006). Functional and selective RNA interference in developing axons and growth cones. Journal Neurosci 26 5727-5732.

Henke Jl, Goergen D, Zheng J, Song Y, Schuttler CG, Fehr C et al (2008). microRNA-122 stimulates translation of hepatitis C virus RNA. EMBO J 27: 3300-3310.

Heo I, Joo C, Kim YK, Ha M, Yoon MJ, Cho J et al (2009). TUT4 in concert with Lin28 suppresses microRNA biogenesis through pre-microRNA uridylation. Cell 138: $696-708$

Hollander JA, Im HI, Amelio AL, Kocerha J, Bali P, Lu Q et al (2010). Striatal microRNA controls cocaine intake through CREB signalling. Nature 466: 197-202.

Hornstein E, Mansfield JH, Yekta S, Hu JK, Harfe BD, McManus MT et al (2005). The microRNA miR-196 acts upstream of Hoxb8 and Shh in limb development. Nature 438: 671-674.

Humphreys DT, Westman BJ, Martin DI, Preiss T (2005). MicroRNAs control translation initiation by inhibiting eukaryotic initiation factor 4E/cap and poly(A) tail function. Proc Natl Acad Sci USA 102: 16961-16966.

Hutvagner G, McLachlan J, Pasquinelli AE, Balint E, Tuschl T, Zamore PD (2001). A cellular function for the RNA-interference enzyme Dicer in the maturation of the let-7 small temporal RNA. Science 293: 834-838.

Hutvagner G, Zamore PD (2002). A microRNA in a multiple-turnover RNAi enzyme complex. Science 297: 2056-2060.

Im HI, Hollander JA, Bali P, Kenny PJ (2010). MeCP2 controls BDNF expression and cocaine intake through homeostatic interactions with microRNA-212. Nat Neurosci 13: 1120-1127.

Im HI, Kenny PJ (2012). MicroRNAs in neuronal function and dysfunction. Trends Neurosci 35: 325-334

Impey S, Davare M, Lesiak A, Fortin D, Ando H, Varlamova O et al (2010). An activity-induced microRNA controls dendritic spine formation by regulating Rac1PAK signaling. Mol Cell Neurosci 43: 146-156.

Jakymiw A, Lian S, Eystathioy T, Li S, Satoh M, Hamel JC et al (2005). Disruption of GW bodies impairs mammalian RNA interference. Nat Cell Biol 7: 1267-1274.

Jakymiw A, Pauley KM, Li S, Ikeda K, Lian S, Eystathioy T et al (2007). The role of GW/P-bodies in RNA processing and silencing. J Cell Sci 120: 1317-1323.

Johnson R, Zuccato C, Belyaev ND, Guest DJ, Cattaneo E, Buckley NJ (2008). A microRNA-based gene dysregulation pathway in Huntington's disease. Neurobiol Dis 29: 438-445.

Johnston RJ, Hobert O (2003). A microRNA controlling left/right neuronal asymmetry in Caenorhabditis elegans. Nature 426: 845-849.

Jones MR, Quinton LJ, Blahna MT, Neilson JR, Fu S, Ivanov AR et al (2009). Zcchc11-dependent uridylation of microRNA directs cytokine expression. Nat Cell Biol 11: 1157-1163.

Jung H, Yoon BC, Holt CE (2012). Axonal mRNA localization and local protein synthesis in nervous system assembly, maintenance and repair. Nat Rev Neurosci 13: 308-324.

Jupe ER, Liu XT, Kiehlbauch JL, McClung JK, Dell'Orco RT (1996). The 3' untranslated region of prohibitin and cellular immortalization. Exp Cell Res 224: 128-135

Kanellopoulou C, Muljo SA, Kung AL, Ganesan S, Drapkin R, Jenuwein T et al (2005). Dicer-deficient mouse embryonic stem cells are defective in differentiation and centromeric silencing. Genes Dev 19: 489-501. 
Karreth FA, Tay Y, Perna D, Ala U, Tan SM, Rust AG et al (2011). In vivo identification of tumor- suppressive PTEN ceRNAs in an oncogenic BRAF-induced mouse model of melanoma. Cell 147: 382-395.

Katoh T, Sakaguchi Y, Miyauchi K, Suzuki T, Kashiwabara S, Baba T et al (2009). Selective stabilization of mammalian microRNAs by $3^{\prime}$ adenylation mediated by the cytoplasmic poly(A) polymerase GLD-2. Genes Dev 23: 433-438.

Kedersha N, Stoecklin G, Ayodele M, Yacono P, Lykke-Andersen J, Fritzler MJ et al (2005). Stress granules and processing bodies are dynamically linked sites of mRNP remodeling. J Cell Biol 169: 871-884.

Ketting RF, Fischer SE, Bernstein E, Sijen T, Hannon GJ, Plasterk RH (2001). Dicer functions in RNA interference and in synthesis of small RNA involved in developmental timing in C. elegans. Genes Dev 15: 2654-2659.

Khvorova A, Reynolds A, Jayasena SD (2003). Functional siRNAs and miRNAs exhibit strand bias. Cell 115: 209-216.

Kim J, Inoue K, Ishii J, Vanti WB, Voronov SV, Murchison E et al (2007). A MicroRNA feedback circuit in midbrain dopamine neurons. Science 317: 1220-1224.

Kim YK, Yeo J, Ha M, Kim B, Kim VN (2011). Cell adhesion-dependent control of microRNA decay. Mol Cell 43: 1005-1014.

Knight SW, Bass BL (2001). A role for the RNase III enzyme DCR-1 in RNA interference and germ line development in Caenorhabditis elegans. Science 293: 2269-2271.

Konecna A, Heraud JE, Schoderboeck L, Raposo AA, Kiebler MA (2009). What are the roles of microRNAs at the mammalian synapse? Neurosci Lett 466: 63-68.

Kosik KS (2006). The neuronal microRNA system. Nat Rev Neurosci 7: 911-920.

Krek A, Grun D, Poy MN, Wolf R, Rosenberg L, Epstein EJ et al (2005). Combinatorial microRNA target predictions. Nat Genet 37: 495-500.

Krichevsky AM, King KS, Donahue CP, Khrapko K, Kosik KS (2003). A microRNA array reveals extensive regulation of microRNAs during brain development. RNA 9: $1274-1281$.

Krol J, Busskamp V, Markiewicz I, Stadler MB, Ribi S, Richter J et al (2010). Characterizing light-regulated retinal microRNAs reveals rapid turnover as a common property of neuronal microRNAs. Cell 141: 618-631.

Kuhn DE, Nuovo GJ, Martin MM, Malana GE, Pleister AP, Jiang J et al (2008). Human chromosome 21-derived miRNAs are overexpressed in down syndrome brains and hearts. Biochem Biophys Res Commun 370: 473-477.

Kwak PB, Tomari Y (2012). The $\mathrm{N}$ domain of Argonaute drives duplex unwinding during RISC assembly. Nat Struct Mol Biol 19: 145-151.

Lagos-Quintana M, Rauhut R, Lendeckel W, Tuschl T (2001). Identification of novel genes coding for small expressed RNAs. Science 294: 853-858.

Lagos-Quintana M, Rauhut R, Yalcin A, Meyer J, Lendeckel W, Tuschl T (2002). Identification of tissue-specific microRNAs from mouse. Curr Biol 12: 735-739.

Landgraf P, Rusu M, Sheridan R, Sewer A, lovino N, Aravin A et al (2007). A mammalian microRNA expression atlas based on small RNA library sequencing. Cell 129: 1401-1414

Landthaler M, Gaidatzis D, Rothballer A, Chen PY, Soll SJ, Dinic L et al (2008). Molecular characterization of human Argonaute-containing ribonucleoprotein complexes and their bound target mRNAs. RNA 14: 2580-2596.

Landthaler M, Yalcin A, Tuschl T (2004). The human DiGeorge syndrome critical region gene 8 and its $D$. melanogaster homolog are required for miRNA biogenesis. Curr Biol 14: 2162-2167.

Lau NC, Lim LP, Weinstein EG, Bartel DP (2001). An abundant class of tiny RNAs with probable regulatory roles in Caenorhabditis elegans. Science 294: 858-862.

Lee RC, Ambros V (2001). An extensive class of small RNAs in Caenorhabditis elegans. Science 294: 862-864.

Lee RC, Feinbaum RL, Ambros V (1993). The C. elegans heterochronic gene lin-4 encodes small RNAs with antisense complementarity to lin-14. Cell 75: 843-854.

Lee Y, Ahn C, Han J, Choi H, Kim J, Yim J et al (2003). The nuclear RNase III Drosha initiates microRNA processing. Nature 425: 415-419.

Lee Y, Kim M, Han J, Yeom KH, Lee S, Baek SH et al (2004). MicroRNA genes are transcribed by RNA polymerase II. EMBO J 23: 4051-4060.

Lehrbach NJ, Armisen J, Lightfoot HL, Murfitt KJ, Bugaut A, Balasubramanian S et al (2009). LIN-28 and the poly(U) polymerase PUP-2 regulate let-7 microRNA processing in Caenorhabditis elegans. Nat Struct Mol Biol 16: 1016-1020.

Leucht C, Stigloher C, Wizenmann A, Klafke R, Folchert A, Bally-Cuif L (2008). MicroRNA-9 directs late organizer activity of the midbrain-hindbrain boundary. Nat Neurosci 11: 641-648.

Leung AK, Calabrese JM, Sharp PA (2006). Quantitative analysis of Argonaute protein reveals microRNA-dependent localization to stress granules. Proc Natl Acad Sci USA 103: 18125-18130.

Leung AK, Vyas S, Rood JE, Bhutkar A, Sharp PA, Chang P (2011a). Poly(ADPribose) regulates stress responses and microRNA activity in the cytoplasm. Mol Cell 42: 489-499.

Leung AK, Young AG, Bhutkar A, Zheng GX, Bosson AD, Nielsen CB et al (2011b). Genome-wide identification of Ago2 binding sites from mouse embryonic stem cells with and without mature microRNAs. Nat Struct Mol Biol 18: 237-244.
Lewis BP, Burge CB, Bartel DP (2005). Conserved seed pairing, often flanked by adenosines, indicates that thousands of human genes are microRNA targets. Cell 120: 15-20.

Lewis MA, Quint E, Glazier AM, Fuchs H, De Angelis MH, Langford C et al (2009). An ENU-induced mutation of miR-96 associated with progressive hearing loss in mice. Nat Genet 41: 614-618.

Liang Y, Ridzon D, Wong L, Chen C (2007). Characterization of microRNA expression profiles in normal human tissues. BMC Genomics 8: 166.

Lim LP, Lau NC, Garrett-Engele P, Grimson A, Schelter JM, Castle J et al (2005). Microarray analysis shows that some microRNAs downregulate large numbers of target mRNAs. Nature 433: 769-773.

Lim LP, Lau NC, Weinstein EG, Abdelhakim A, Yekta S, Rhoades MW et al (2003). The microRNAs of Caenorhabditis elegans. Genes Dev 17: 991-1008.

Lin Q, Wei W, Coelho CM, Li X, Baker-Andresen D, Dudley Ket al (2011). The brainspecific microRNA miR-128b regulates the formation of fear-extinction memory. Nat Neurosci 14: 1115-1117.

Lingel A, Simon B, Izaurralde E, Sattler M (2003). Structure and nucleic-acid binding of the Drosophila Argonaute 2 PAZ domain. Nature 426: 465-469.

Liu J, Carmell MA, Rivas FV, Marsden CG, Thomson JM, Song JJ et al (2004). Argonaute2 is the catalytic engine of mammalian RNAi. Science 305: 1437-1441.

Liu J, Rivas FV, Wohlschlegel J, Yates JR, Parker III R, Hannon GJ (2005a). A role for the P-body component GW182 in microRNA function. Nat Cell Biol 7: 1261-1266.

Liu J, Valencia-Sanchez MA, Hannon GJ, Parker R (2005b). MicroRNA-dependent localization of targeted mRNAs to mammalian P-bodies. Nat Cell Biol 7: 719-723.

Lugli G, Larson J, Martone ME, Jones Y, Smalheiser NR (2005). Dicer and elF2c are enriched at postsynaptic densities in adult mouse brain and are modified by neuronal activity in a calpain-dependent manner. J Neurochem 94: 896-905.

Lugli G, Torvik VI, Larson J, Smalheiser NR (2008). Expression of microRNAs and their precursors in synaptic fractions of adult mouse forebrain. J Neurochem 106: 650-661.

Lukiw WJ (2007). Micro-RNA speciation in fetal, adult and Alzheimer's disease hippocampus. Neuroreport 18: 297-300.

Lund E, Guttinger S, Calado A, Dahlberg JE, Kutay U (2004). Nuclear export of microRNA precursors. Science 303: 95-98.

Lutter D, Marr C, Krumsiek J, Lang EW, Theis FJ (2010). Intronic microRNAs support their host genes by mediating synergistic and antagonistic regulatory effects. BMC Genomics 11: 224

Makeyev EV, Zhang J, Carrasco MA, Maniatis T (2007). The MicroRNA miR-124 promotes neuronal differentiation by triggering brain-specific alternative premRNA splicing. Mol Cell 27: 435-448.

Megraw M, Hatzigeorgiou AG (2010). MicroRNA promoter analysis. Methods Mol Biol 592: 149-161.

Meister G, Landthaler M, Patkaniowska A, Dorsett Y, Teng G, Tuschl T (2004). Human Argonaute2 mediates RNA cleavage targeted by miRNAs and siRNAs. Mol Cell 15: 185-197

Miller BH, Zeier Z, Xi L, Lanz TA, Deng S, Strathmann J et al (2012). MicroRNA-132 dysregulation in schizophrenia has implications for both neurodevelopment and adult brain function. Proc Natl Acad Sci USA 109: 3125-3130.

Miska EA, Alvarez-Saavedra E, Townsend M, Yoshii A, Sestan N, Rakic P et al (2004). Microarray analysis of microRNA expression in the developing mammalian brain. Genome Biol 5: R68.

Mollet S, Cougot N, Wilczynska A, Dautry F, Kress M, Bertrand E et al (2008). Translationally repressed mRNA transiently cycles through stress granules during stress. Mol Biol Cell 19: 4469-4479.

Monteys AM, Spengler RM, Wan J, Tecedor L, Lennox KA, Xing Y et al (2010). Structure and activity of putative intronic miRNA promoters. RNA 16: 495-505

Morita S, Horii T, Kimura M, Goto Y, Ochiya T, Hatada I (2007). One Argonaute family member, Eif2c2 (Ago2), is essential for development and appears not to be involved in DNA methylation. Genomics 89: 687-696.

Morlando M, Ballarino M, Gromak N, Pagano F, Bozzoni I, Proudfoot NJ (2008). Primary microRNA transcripts are processed co-transcriptionally. Nat Struct $\mathrm{Mol}$ Biol 15: 902-909.

Napper RM, Harvey RJ (1988a). Number of parallel fiber synapses on an individual Purkinje cell in the cerebellum of the rat. J Compar Neurol 274: 168-177.

Napper RM, Harvey RJ (1988b). Quantitative study of the Purkinje cell dendritic spines in the rat cerebellum. J Compar Neurol 274: 158-167.

Natera-Naranjo O, Aschrafi A, Gioio AE, Kaplan BB (2010). Identification and quantitative analyses of microRNAs located in the distal axons of sympathetic neurons. RNA 16: 1516-1529.

Nudelman AS, DiRocco DP, Lambert TJ, Garelick MG, Le J, Nathanson NM et al (2010). Neuronal activity rapidly induces transcription of the CREB-regulated microRNA-132, in vivo. Hippocampus 20: 492-498.

Obernosterer G, Leuschner PJ, Alenius M, Martinez J (2006). Post-transcriptiona regulation of microRNA expression. RNA 12: 1161-1167. 
O'Carroll D, Mecklenbrauker I, Das PP, Santana A, Koenig U, Enright AJ et al (2007). A Slicer-independent role for Argonaute 2 in hematopoiesis and the microRNA pathway. Genes Dev 21: 1999-2004.

Okamura K, Hagen JW, Duan H, Tyler DM, Lai EC (2007). The mirtron pathway generates microRNA-class regulatory RNAs in Drosophila. Cell 130: 89-100.

Olde Loohuis NF, Kos A, Martens GJ, Van Bokhoven H, Nadif Kasri N, Aschrafi A (2012). MicroRNA networks direct neuronal development and plasticity. Cell Mol life Sci 69: 89-102.

Olsen L, Klausen M, Helboe L, Nielsen FC, Werge T (2009). MicroRNAs show mutually exclusive expression patterns in the brain of adult male rats. PloS One 4: e7225.

Orom UA, Nielsen FC, Lund AH (2008). MicroRNA-10a binds the 5'UTR of ribosomal protein mRNAs and enhances their translation. Mol Cell 30: 460-471.

Ozsolak F, Poling LL, Wang Z, Liu H, Liu XS, Roeder RG et al (2008). Chromatin structure analyses identify miRNA promoters. Genes Dev 22: 3172-3183.

Packer AN, Xing Y, Harper SQ, Jones L, Davidson BL (2008). The bifunctional microRNA miR-9/miR-9* regulates REST and CoREST and is downregulated in Huntington's disease. J Neurosci 28: 14341-14346.

Paroo Z, Ye X, Chen S, Liu Q (2009). Phosphorylation of the human microRNAgenerating complex mediates MAPK/Erk signaling. Cell 139: 112-122.

Pasquinelli AE, Reinhart BJ, Slack F, Martindale MQ, Kuroda MI, Maller B et al (2000). Conservation of the sequence and temporal expression of let-7 heterochronic regulatory RNA. Nature 408: 86-89.

Patrick DM, Zhang CC, Tao Y, Yao H, Qi X, Schwartz RJ et al (2010). Defective erythroid differentiation in miR-451 mutant mice mediated by 14-3-3zeta. Genes Dev 24: 1614-1619.

Pena JT, Sohn-Lee C, Rouhanifard SH, Ludwig J, Hafner M, Mihailovic A et al (2009). miRNA in situ hybridization in formaldehyde and EDC-fixed tissues. Nat Methods 6: 139-141.

Perkins DO, Jeffries CD, Jarskog LF, Thomson JM, Woods K, Newman MA et al (2007). microRNA expression in the prefrontal cortex of individuals with schizophrenia and schizoaffective disorder. Genome Biol 8: R27.

Pichardo-Casas I, Goff LA, Swerdel MR, Athie A, Davila J, Ramos-Brossier M et al (2012). Expression profiling of synaptic microRNAs from the adult rat brain identifies regional differences and seizure-induced dynamic modulation. Brain Res 1436: 20-33.

Pietrzykowski AZ, Friesen RM, Martin GE, Puig SI, Nowak CL, Wynne PM et al (2008). Posttranscriptional regulation of BK channel splice variant stability by miR-9 underlies neuroadaptation to alcohol. Neuron 59: 274-287.

Pillai RS, Bhattacharyya SN, Artus CG, Zoller T, Cougot N, Basyuk E et al (2005). Inhibition of translational initiation by Let-7 MicroRNA in human cells. Science 309: 1573-1576.

Poliseno L, Salmena L, Zhang J, Carver B, Haveman WJ, Pandolfi PP (2010). A coding-independent function of gene and pseudogene mRNAs regulates tumour biology. Nature 465: 1033-1038.

Qi HH, Ongusaha PP, Myllyharju J, Cheng D, Pakkanen O, Shi Y et al (2008). Prolyl 4-hydroxylation regulates Argonaute 2 stability. Nature 455: 421-424.

Radfar $\mathrm{MH}$, Wong W, Morris Q (2011). Computational prediction of intronic microRNA targets using host gene expression reveals novel regulatory mechanisms. PloS One 6: e19312.

Rajasethupathy P, Fiumara F, Sheridan R, Betel D, Puthanveettil SV, Russo JJ et al (2009). Characterization of small RNAs in Aplysia reveals a role for miR-124 in constraining synaptic plasticity through CREB. Neuron 63: 803-817.

Rao PK, Toyama Y, Chiang HR, Gupta S, Bauer M, Medvid R et al (2009). Loss of cardiac microRNA-mediated regulation leads to dilated cardiomyopathy and heart failure. Circ Res 105: 585-594.

Rasmussen KD, O'Carroll D (2011). The miR-144/451eGFP allele, a novel tool for resolving the erythroid potential of hematopoietic precursors. Blood 118: 2988-2992.

Rasmussen KD, Simmini S, Abreu-Goodger C, Bartonicek N, Di Giacomo M, Bilbao-Cortes D et al (2010). The miR-144/451 locus is required for erythroid homeostasis. J Exp Med 207: 1351-1358.

Rastinejad F, Conboy MJ, Rando TA, Blau HM (1993). Tumor suppression by RNA from the $3^{\prime}$ untranslated region of alpha-tropomyosin. Cell 75: 1107-1117.

Raymond CK, Roberts BS, Garrett-Engele P, Lim LP, Johnson JM (2005). Simple, quantitative primer-extension PCR assay for direct monitoring of microRNAs and short-interfering RNAs. RNA 11: 1737-1744.

Rehwinkel J, Behm-Ansmant I, Gatfield D, Izaurralde E (2005). A crucial role for GW182 and the DCP1:DCP2 decapping complex in miRNA-mediated gene silencing. RNA 11: 1640-1647.

Reinhart BJ, Slack FJ, Basson M, Pasquinelli AE, Bettinger JC, Rougvie AE et al (2000). The 21-nucleotide let-7 RNA regulates developmental timing in Caenorhabditis elegans. Nature 403: 901-906.

Ripke S, Sanders AR, Kendler KS, Levinson DF, Sklar P, Holmans PA et al (2011). Genome-wide association study identifies five new schizophrenia loci. Nat Genet 43. 969-976.
Rodriguez A, Griffiths-Jones S, Ashurst JL, Bradley A (2004). Identification of mammalian microRNA host genes and transcription units. Genome Res 14: 1902-1910.

Ruby JG, Jan CH, Bartel DP (2007). Intronic microRNA precursors that bypass Drosha processing. Nature 448: 83-86.

Rudel S, Wang Y, Lenobel R, Korner R, Hsiao HH, Urlaub H et al (2010). Phosphorylation of human Argonaute proteins affects small RNA binding Nucleic Acids Res 39: 2330-2343.

Rybak A, Fuchs H, Hadian K, Smirnova L, Wulczyn EA, Michel G et al (2009). The let-7 target gene mouse lin-41 is a stem cell specific E3 ubiquitin ligase for the miRNA pathway protein Ago2. Nat Cell Biol 11: 1411-1420.

Schaefer A, Im HI, Veno MT, Fowler CD, Min A, Intrator A et al (2010). Argonaute 2 in dopamine 2 receptor-expressing neurons regulates cocaine addiction. J Exp Med 207: 1843-1851.

Schaefer A, O'Carroll D, Tan CL, Hillman D, Sugimori M, Llinas R et al (2007). Cerebellar neurodegeneration in the absence of microRNAs. J Exp Med 204: 1553-1558.

Schaefer A, Sampath SC, Intrator A, Min A, Gertler TS, Surmeier DJ et al (2009). Control of cognition and adaptive behavior by the GLP/G9a epigenetic suppressor complex. Neuron 64: 678-691.

Schratt G (2009). microRNAs at the synapse. Nat Rev Neurosci 10: 842-849.

Schratt GM, Tuebing F, Nigh EA, Kane CG, Sabatini ME, Kiebler M et al (2006). A brain-specific microRNA regulates dendritic spine development. Nature 439: 283-289.

Schwarz DS, Hutvagner G, Du T, Xu Z, Aronin N, Zamore PD (2003). Asymmetry in the assembly of the RNAi enzyme complex. Cell 115: 199-208.

Selbach M, Schwanhausser B, Thierfelder N, Fang Z, Khanin R, Rajewsky N (2008). Widespread changes in protein synthesis induced by microRNAs. Nature 455: 58-63.

Sempere LF, Freemantle S, Pitha-Rowe I, Moss E, Dmitrovsky E, Ambros V (2004). Expression profiling of mammalian microRNAs uncovers a subset of brainexpressed microRNAs with possible roles in murine and human neuronal differentiation. Genome Biol 5: R13.

Sen GL, Blau HM (2005). Argonaute 2/RISC resides in sites of mammalian mRNA decay known as cytoplasmic bodies. Nat Cell Biol 7: 633-636.

Shao NY, Hu HY, Yan Z, Xu Y, Hu H, Menzel C et al (2010). Comprehensive survey of human brain microRNA by deep sequencing. BMC Genomics 11: 409.

Sheth U, Parker R (2003). Decapping and decay of messenger RNA occur in cytoplasmic processing bodies. Science 300: 805-808.

Siegel G, Obernosterer G, Fiore R, Oehmen M, Bicker S, Christensen M et al (2009). A functional screen implicates microRNA-138-dependent regulation of the depalmitoylation enzyme APT1 in dendritic spine morphogenesis. Nat Cell Biol 11: $705-716$

Siegel G, Saba R, Schratt G (2011). microRNAs in neurons: manifold regulatory roles at the synapse. Curr Opin Genet Dev 21: 491-497.

Smalheiser NR, Lugli G (2009). microRNA regulation of synaptic plasticity. Neuromol Med 11: 133-140.

Smalheiser NR, Lugli G, Torvik VI, Mise N, Ikeda R, Abe K (2008). Natural antisense transcripts are co-expressed with sense mRNAs in synaptoneurosomes of adult mouse forebrain. Neurosci Res 62: 236-239.

Song JJ, Liu J, Tolia NH, Schneiderman J, Smith SK, Martienssen RA et al (2003). The crystal structure of the Argonaute2 PAZ domain reveals an RNA binding motif in RNAi effector complexes. Nat Struct Biol 10: 1026-1032.

Stark KL, Xu B, Bagchi A, Lai WS, Liu H, Hsu R et al (2008). Altered brain microRNA biogenesis contributes to phenotypic deficits in a 22q11-deletion mouse model. Nat Genet 40: 751-760.

Steward O, Schuman EM (2003). Compartmentalized synthesis and degradation of proteins in neurons. Neuron 40: 347-359.

Sun G, Yan J, Noltner K, Feng J, Li H, Sarkis DA et al (2009). SNPs in human miRNA genes affect biogenesis and function. RNA 15: 1640-1651.

Suzuki HI, Arase M, Matsuyama H, Choi YL, Ueno T, Mano H et al (2011). MCPIP1 ribonuclease antagonizes dicer and terminates microRNA biogenesis through precursor microRNA degradation. Mol Cell 44: 424-436.

Tan GS, Garchow BG, Liu X, Metzler D, Kiriakidou M (2011). Clarifying mammalian $\mathrm{RISC}$ assembly in vitro. BMC Mol Biol 12: 19

Tay Y, Kats L, Salmena L, Weiss D, Tan SM, Ala U et al (2011). Coding-independent regulation of the tumor suppressor PTEN by competing endogenous mRNAs. Cell 147: 344-357.

Tsukamoto T, Yoo J, Hwang SI, Guzman RC, Hirokawa Y, Chou YC et al (2000). Expression of MAT1/PEA-15 mRNA isoforms during physiological and neoplastic changes in the mouse mammary gland. Cancer Lett 149: 105-113.

Vasudevan S, Tong Y, Steitz JA (2007). Switching from repression to activation: microRNAs can up-regulate translation. Science 318: 1931-1934.

Ventura A, Young AG, Winslow MM, Lintault L, Meissner A, Erkeland SJ et al (2008). Targeted deletion reveals essential and overlapping functions of the miR-17 through 92 family of miRNA clusters. Cell 132: 875-886. 
Vo N, Klein ME, Varlamova O, Keller DM, Yamamoto T, Goodman RH et al (2005). A cAMP-response element binding protein-induced microRNA regulates neuronal morphogenesis. Proc Natl Acad Sci USA 102: 16426-16431.

Wang D, Lu M, Miao J, Li T, Wang E, Cui Q (2009). Cepred: predicting the coexpression patterns of the human intronic microRNAs with their host genes. PloS One 4: e4421.

Wang Y, Medvid R, Melton C, Jaenisch R, Blelloch R (2007). DGCR8 is essential for microRNA biogenesis and silencing of embryonic stem cell self-renewal. Nat Genet 39: 380-385.

Wayman GA, Davare M, Ando H, Fortin D, Varlamova O, Cheng HY et al (2008). An activity-regulated microRNA controls dendritic plasticity by down-regulating p250GAP. Proc Natl Acad Sci USA 105: 9093-9098.

Wienholds E, Kloosterman WP, Miska E, Alvarez-Saavedra E, Berezikov E, de Bruijn $\mathrm{E}$ et al (2005). MicroRNA expression in zebrafish embryonic development. Science 309: 310-311.

Yan KS, Yan S, Faroog A, Han A, Zeng L, Zhou MM (2003). Structure and conserved RNA binding of the PAZ domain. Nature 426: 468-474.

Yang JS, Maurin T, Robine N, Rasmussen KD, Jeffrey KL, Chandwani R et al (2010). Conserved vertebrate mir-451 provides a platform for Dicer-independent, Ago2mediated microRNA biogenesis. Proc Natl Acad Sci USA 107: 15163-15168.

Yekta S, Shih IH, Bartel DP (2004). MicroRNA-directed cleavage of HOXB8 mRNA. Science 304: 594-596.

Yi R, Pasolli HA, Landthaler M, Hafner M, Ojo T, Sheridan R et al (2009). DGCR8dependent microRNA biogenesis is essential for skin development. Proc Natl Acad Sci UA 106: 498-502.

Yi R, Qin Y, Macara IG, Cullen BR (2003). Exportin-5 mediates the nuclear export of pre-microRNAs and short hairpin RNAs. Genes Dev 17: 3011-3016.

Yoo AS, Staahl BT, Chen L, Crabtree GR (2009). MicroRNA-mediated switching of chromatin-remodelling complexes in neural development. Nature 460 642-646.

Yoo AS, Sun AX, Li L, Shcheglovitov A, Portmann T, Li Y et al (2011). MicroRNAmediated conversion of human fibroblasts to neurons. Nature 476: 228-231.

Yu D, dos Santos CO, Zhao G, Jiang J, Amigo JD, Khandros E et al (2010). miR-451 protects against erythroid oxidant stress by repressing 14-3-3zeta. Genes Dev 24: 1620-1633.

Zeng Y, Sankala H, Zhang X, Graves PR (2008). Phosphorylation of Argonaute 2 at serine-387 facilitates its localization to processing bodies. Biochem J 413 429-436 